\title{
HUKUK SOSYOLOJISI
}

\section{MEDENî KANUN ELEŞTIRİLERİ I :}

\section{KARININ IKTISADEN KORUNMASI}

Dr. Ülker GURKaN

Hukuk Sosyolojisi Doçenti

\section{GtRIș}

19. yüzyll sonlarında hukukta temel görüşleri değiștiren bir akım başlamıştır. Bu hem tabiî hukuk anlayışına hem de bu çağın ekonomik kökenli liberal diuşüncesinin aşır ferdiyetçiliğine kar. ş1 bir reaksiyonu ifade eder. Bu durum hukukun sosyalleştirilmesi gereğinin idrâkidir. Hukukun sosyalleștirilmesi safhasında artık hukukçular tabiî hakların gerisindeki menfaat durumlanyla ilgilenmeğe başlamışlardır. Buun sonucu olarak ta tabiî haklardan sosyal haklara, sosyal menfaatlere doğru bir gelişme başlamış ve pek çok modern hukuk sistemlerince benimsenmiştir ${ }^{1}$.

Hukukun sosyalleşmesinin çeşitli hukuk dallarındaki etkisi büyük olmuş, bu meyanda aile hukuku alanında da büyük devrimler yapılmıştır. Çeşitli toplumlarda aile hukuku alanında görülen değişiklikler, içinde bulunduğumuz çağın başlarından başlayarak I. ve II. Cihan Savaşlarından sonra giderek hızlanan bir tempo göstermektidir. Bunda sosyal adâlet duygusu, kadının bağımsızlığını kazanması (emansipasyonu), kadını iş hayatına iten zorunluluklar ve bütün bunların sonucu olarak ta kadın erkek ilişkileri hakkında değișen değer yargıları rol oynamaktadır. Böylece toplumun kendi çekirdeği olan aile dïzenine ve hattâ fertlerin kendi özel menfaatlerinin korunmasına karşı ilgisi antmakta; modern kanun koyucuları da hayatı izleme zorunluluğu karșısında aileye ve üyelerine ilişkin sorunları yeniden ele alıp, yeni düzenlemelere gitmektedirler.

1 R. Pound, "The End of Law as Developed in Legal Rules and Doctrinesn, 27 Harv. L. Rev. sh. 220-224. 
Kanun koyucularn yeni tutumlar takınmağa zorlayan etkenlerin başında kanun önünde eșitlik ilkesinin ailede karı koca yönünden gerçekleştirilmesini görmekteyiz. Böylece, aile de kadının yetkileri artırılır, ona yeni haklar tanmırken, iktisaden korunması sorunu da ortaya çıkmaktadır. Bu nedenle, özellikle son on yılda "mal rejimleri», "nafaka» ve "miras hukuku» alanlarında karn lehine olmak üzere yeni çözüm tarzları aranmakta ve bulunmaktadır ${ }^{2}$.

1926 yılında bir «hukuk âbidesi» telâkki edilen İsviçre Medenî Kanununu (ZGB) iktibas ederek Batı Hukuk Sistemi içerisinde yer aldığımıza, kadın erkek eșitliğini beyan eden milletlerarası beyannâmeleri onayladığımıza ve nihayet Anayasamızda bu ilkeye yer vermiş bulunduğumuza göre, yukarnda sözii edilen sorunları, Batı toplumlarındaki hukukî gelișmeleri de izleyerek, tekrar ele almamız gerekmektedir.

Şurası bir gerçektir ki, Isviçre M.K. nu (ZGB) 1907 ylında kabul edilmiş olması nedeniyle, günümüzün sosyal ihtiyaç ve zihniyetine göre geri kalmıştır. Ayrıca ZGB nin çeșitli Kanton hukuk sistemlerinin bir mułıassalası olduğunu, bu nedenle bazı konularda "ideal çözümler» yerine «uzlaștırıcı» yani «sun'î çözümler»e yer ver. diğini $\mathrm{de}^{3}$ unutmamak gerekir. Nitekim bu durumu idrak eden İs. viçreliler de kendi Medeni Kanunların ıçeşitli noktalarda değiştir. mişlerdir ve değiştirmektedirler ${ }^{4}$. Artık bu durumda Medeni Kanunumuza ilişkin çeșitli sorunların teker teker ele alınması zamani gelmiştir kanısındayız.

Daha çok sosyolojik açıdan ele aldığımız bu araştırmada M.K. muzun bir kaç sorununa, ezcümle kadın erkek eșitliğinden hareketle, kadının iktisaden korunması için boşanma, miras ve bununla yakın ilgisi olan mal rejimleri hükümlerine, bunlarnn değișen șart. lara ve sosyal ihtiyaçlara uydurulması gereğine değinecȩ̧iz. Bu sorunların henüz toplumun malı olmadığını, pek az kişi tarafından idrâk ve kabul edildiğini bilmekteyiz. Amacımız bu alanda gerçek uzmanlar olan özel hukukçularımızın dikkatlerini çekebilmektedir. Böylece eski zihniyeti büyük ölçüde muhafaza eder görünen «Medenî Kanun Öntasarısı'nın Parlâmentoya intikâlinden önce, bu so-

\footnotetext{
${ }^{2}$ Avrupa ülkelerinde yapılan reformlar listesi için bkz.: S. Boschan, Europäisches Familienrecht, 5. Auflage, München 1972, Vorwort, sh. V-VI.

${ }^{3}$ M. Aksoy, Mukayeseli Hukuk Açısından Karı Koca Mal Rejimi ve Miras Hukuku ile Bağı, Ankara 1964, sh. 4.

4 Aksoy, a.g.e., sh. 84.
} 
runların daha yetkili kişilerce tartışılıp olgunlaştırılacağını ümid etmekteyiz.

\section{§ 1 - Sosyal Değişmelerin Alleye Etkisi :}

Müesseseler toplumsal hayatın ürünleridir. Insanlar ihtiyaçlarını karşılayacak pratik yolları daima arar ve bulurlar. Bu bulunan. ların tekrarlanmasıyla da karşımıza davranış biçimleri, örfler, deger yargıları, kurallar ve bunları kapsayan müesseseler çkar, İnsiyaklar hayvan davranıșlarına nasıl yön verirse, müiesseseler de insan davranışlarım öylece biçimlendirir ve yönetirler. Ancak hayvan toplumlarında hayvan davranışlan ayn biçimi muhafaza ettiği halde, insan davranışlan ve dolayısıyla müesseseleri de değişir. Kısacası, insan müesseselerin hem bìr tâbiî hem de yaratıcısı ve değiștiricisidir.

Aile tüm müesseselerin en sürekli ve yaygın, birincil gruplarin (primary groups) en önemlisi ve sosyalizasyon sürecinin en etkilisi olması nedeniyle, beşerî toplumsal hayatın vaz geçilmez unsurudur ${ }^{5}$. Ailede beşer hayatının dört temel fonksiyonu yer almıştır : Cinsel, ekonomik, üreme ve egittme. Birinci ve üçüncü fonksiyon olmastydı toplum da olmazd. Ikincinin yokluğu halinde hayatın kendisi durur. Nihayet sonucunun yokluğu halinde kültür. den söz edilemezdi. Isște ailenin sosyal faydası ve evrenselliği burada karşımıza çıkmaktadır ${ }^{6}$.

Aile her zaman ve her yerde aynı kalmamıştır. Bir toplumdaki hâkimiyet sistemi, coğrafî yap1, iklim, ekonomik durum ve üretim tarzı, kültürün gelişme biçimi ve diğer kültürlerin etkisi aileyi farkh biçimlendirdiği gibi, üyeleri arasındaki ilişkileri de farklı tayin eder ${ }^{7}$. Ancak yukanda belirttiğimiz üzere, insan müiessesesinin tâbiî olduğu kadar yenileyicisi ve değiştiricisidir de. Bu nedenle gerek iç etkenler diyebileceğimiz aile üyelerinin davranış biçimleri, tutumları ve zihniyetleri, gerekse sosyal, ekonomik, kültürel v.b. gibi çeşitli diş etkenler zamanla insan davranışlarında ve dolayısıyla aile müessesesinde degişmelere yol açar. Tarmmsal ve göçebe toplumlarda hayatın akışını değiștiren etkenler az ve katı olduğundan, muiesseselerde değişme çok yavaş cereyan eder. Buna karşllk canlı

\footnotetext{
${ }^{5}$ H. M. Hodges, In Introduction to Sociology, New York 1971, sh. 262.

6 N. W. Bell - E. F. Vogel, The Family, New York 1968, (Hodges nak. a.g.e., sh. 262).

${ }^{7}$ Bkz. R. Mayntz, Die Moderne Familie, Stuttgart 1955, sh. 5.
} 
endüstri toplumlarındaki müesseseler, sürekli değişmelerin yarattı ğı kararsızlıkların nimetlerinden büyük ölçüde yararlanır.

Duygusal hayatımızla çok yakından ilgili olan aile müessese. sinin değiş̧imi her tür toplumda çok yavaş cereyan etmiștir. Aile biçimlerinin kadının ve kadın soyunun hâkim olduğu ana-erkil aile. den erkek ile erkek soyunun hâkim olduğu baba-erkil aileye dönüşümü, çok karnlı veya kocalı evlilikten (poligami, poliandri) tek evliliğe (monogami), içinde tâli aileleri (erkek ve kız çocukların, toruların ailelerini) barındıran geniș ailenin çekirdek aileye (ana, ba. ba ve çocukların teşkil ettiğgi aile) yönelişi yüzyıllan gerektirmiş. tir. Konumuz yönünden bizi ilgilendiren bu son safhada, yeni 19. ve 20. yüzyılda hız kazanan sosyal değişmelerin aile müessesesinde ortaya çıkardığı değişmeler ve bu değişmelerde rol oynayan etkenlerdir.

19. yüzyılın sonlarindan başlayarak, Fransız Devriminin bayrakdarı olduğu aşırı ferdiyetçiliğin yavaş yavaş ortadan kalktığına şahit olunmaktadır. Artık toplum menfaatı ağır basmaktadır. Pound'un da belirttiği üzere, özellikle 20. yüzyll toplumsal menfaatlerin önem kazandığı ve bu menfaat grubu içersinde fertler, gruplar ve fertlerle gruplar arası çeșitli menfaatlerin ${ }^{8}$ değerlendirilip denkleștirilmesinin, uyumlu kllınmasının ağır bastığı bir dönem olarak belirtmektedir. Bu nedenle ferdin hürriyetleri sınılandinlmış, ona ağır sorumluluklar yüklenmiştir. Fert artık eski hukuk anlayışında olduğu gibi sübjektif haklardan mutlak şekilde yararlanamamaktadır. Ferde tanınan hakların sosyal bir fonksiyonu vardır ve bu hakların kapsamın bu görev belirler. Ayrica hakların kul. lanılması, kamu yararına da aykırı olmayacaktır ${ }^{9}$. Böylece mülkiyet hakkı, akit serbestisi ${ }^{10}$ büyük ölçüide sınırlandırılmıștır.

\footnotetext{
8 Pound, menfaat terimini Bentham'ın kulfandığı basit ve ilkel anlamda ele almaz. Bu terimi Jhering'in "hukuken korunan menfaatlar" kavramı ve James'in wetik miikellefiyetlerin kaynağını teşkil eden talep ve ihtiyaçlar» kavramı ile karıştırop zenginleştirerek kullanır. Bu menfaatler insatların gerek ferđen, gerek grup ve topluluk içersinde veya birbirleriyle ilişkilerinde tatminini aradıkları arzu, talep ve ihtiyaçların toplamı olup, kanun koyucu tarafından dikkate almmalıdır. Bkz. Pound, A Survey of Social Interests, 57 Harv. L. Rev. sh. 2.

${ }^{9}$ A. Egger, Sosyal Medenî Hukuk veya Bugünkü Medenî Hukukta Cemiyer ve Fert (Çev. H. Veldet), Ankara 1938, sh. 5.

so Pound da Egger gibi, bu kasitlamalarm neticede aile müessesesinin korun. masına yol açtığ kamısındadır. Bkz. Pound, The End of Law as Develo ped in Juristic Thought, sh. 266 v.d.
} 
Bilindiği üzere özel hukuk devletten ayrı olarak fertle ilgilenir. Ancak her hukuk kuralı gibi, özel hukuk kurallar da toplumsal hayattan kaynak aldığı için, bu alanda da topluma ağıriık verilmekte, kısaca ifade etmek gerekirse, özel hukuk sosyalleşmekte, bu yeni özel hukuk ta tüm ülkelerde genel menfaatlere göre düzünlenmek. tedir " Fert hakları toplum tarafindan korunmakla beraber, topluma bağlanmış, bunun sonucu olarak ta özel hukuk ta e ş i t li k f i k r i gelişmiş bulunmaktadır ${ }^{12}$. Bu arada gelişen sosyal adalet duygusu, endüstrileşme, kadının bağımsızlığı uğrundaki mücadeleler ve kadının giderek artan bir oranda is hayatına kayması, kadın erkek ilişkilerinde ve bunlara ilişkin değer yargılarında değișme yaratmış, sonuç olarak ta toplumlarda gerilim ve fiilî durum değişikliklerine yol açmıştır. Bütün bu olaylar ve olgular zinciri siyaseti de etkilemede gecikmemiş, demokratlaşmanun görüildüği her toplumda, aile ata-erkil dïzenini yavaş yavaş yitirerek «eșit haklara dayanan bir hayat ontaklığına» (gleichberechtigte Partnerschaft) dönüşme yoluna girmiștir ${ }^{13}$. Böylece geniş ailenin yerini ana, baba, ve çocuklardan oluşan «küçük aile», «çekirdek aile» almıș, nafaka yükümlülüğui giderek daralmıs, nihayet küçük ailedeki kuvvet dengesi de değişmiştir. Modern kanun koyucular, içerde babanın kudret ve otoritesine dayanan biçimde örgütlenen, dışarıya karşı «aile reisi" sifatiyla «erkek" ve "baba" tarafindan temsil edilen bu son aile tipini yeniden ele alarak aile üyelerinin hukukî durumlarını birbirine bağımlı kılmış ${ }^{14}$, ilişkilerini eșitlik ilkesine göre düzenlemeğe başlamışlardır. Hukukî alandaki bu eşitlik, kadına kamu yararına uygun olarak kendi yeteneklerini geliştirebilmesi ve üzerine düşen görevleri gereğince ifa edebilmesi için tanınmıștır. Gerçekten de modern aile ve toplumda, kadına düșen roller çoğalmıș, bunlara tekabül eden sorumluluklar ise ağırlaşmıștır. Günümüizïn kadını "eş», «ana», "çocuklarun ilk eğiticisi», «ögrretmenin yardımcısı", «ailenin işlerini gören hizmetkâr» ve nihayet "dışarıda çalışan», «bir meslek icra eden» kişi olarak belirtmektedir. Bu rollerin geregince ve hele yeterince ifa edilmesinden aile üyelerinin ve toplumun ne derece yararlanacağ ise ortadadır ${ }^{15}$.

Son çeyrek yüzyılda aile bünyesinde ortaya çıkan durum, yani aile ïyeleri arasında gevșeyen bağlar, değișen ilişkiler, sayısı artan

11 Egger, a.g.e., sh. 7.

12 Egger, a.g.e., sh. 11 v.d.

13 H. Dölle, Familienrecht, Band I, Karlsruhe 1964, sh. 20.

$14 \mathrm{G}$. Boehmer, Einführung in das Bürgerlichen Recht, Tübingen, 1954, sh. 85. 
boşanmalar, hâkimiyete dayanan bağlara ve cinsel ahlâk anlayıșına bir reaksiyon olarak yeni kuşağın aileye karşı takındığı şüpheci tavır, pek çok kişide "aile müessesesinin ortadan kalkmakta» olduğu sanısısı yaratmakta, bu alanda aşırı iddialara yol açmaktadır. Oysa aile müessesesi bir "geçiş dönemi»ndedir. Bünyesinde gözlenen değişmelere rağmen, gelişmiş toplumlarda bile, ataerkil ve muhafazakâr niteliğini pek çok noktada ve büyük ölçüde sürdürmektedir ${ }^{16}$. Bu nedenle, köklï ideolojik bir devrim geçiren S.S.C.B. bir yana brrakılacak olursa, modern kanun koyucular ihtiyaçlara cevap verecek yarnki yeni ailenin dayanacağı hukukî temelleri hazırlama çabasındadırlar. Bunun için 1950 lerden bu yana cinsler arası eșitlik ilkesini anayasalarında beyanla yetinmeyip, tüm mevzuatlarında gerçekleşmesini arnaç edinmişlendir ${ }^{17}$; sosyal âdalet ilkeleri geregince kadına maddî güven sağlama, ona kocanın kazancından bir pay ayırma zorunluluğunu da dikkate almışlardır. Böylece, özellikle boșnan ya da eşi ölen kadına bazı imtiyazlar tanınması konusunda başlayan çalışmalr, ürünlerini verme yolun girmiştir.

\section{\$ 2 - Ailenin Niteliğı :}

Ailenin temelini evlenme teșkil eder. Kanun koyucular evlen. menin tanımını yapmayarak, eşler arasında ortaya çıkan durumu, genellikle bir «birlik», «evlilik birliği» diye nitelendirmişlerdir (ZGB md. 159, Türk M.K. md. 151). Evliliğin cinsel, ahlâkî ve iktisadî yönlerden bir bütün teşkil ettiğini gören alman M.K. nu (BGB) ise bunu $\S 1353$ ile daha isabetli bir şekilde «evlilik hayat birliği» (die eheliche Lebensgemeinschaft) olarak ifade etmiştir.

Kanun koyucuların evlenmeyi tanımlamaktan kaçınmaları tesadüfî değildir. Bu yolla müessesenin dondurulmayarak, toplumsal değişmeleri izlemesi ve canlılığın koruması amaç edinilmiştir. Ni. tekim, doktrin tarafından deruhte edilen tanımlamaların zamanın akışı içersinde, toplumlara göre az çok farklllık göstermesi bunun bir delilidir. Ailenin niteliğini kavrayabilmek için evlenmenin ta. 'umlarından hareket etmek gerekmektedir. Velidedeoğlu'na göre, «Evlenme, tam ve sürekli bir hayat ortaklığ yaratmak üzere cinsi-

\footnotetext{
${ }^{15} \mathrm{Bu}$ gerçeği isabetle teşhis eden Egger, tüm haklardan yararlanmanm ka. dına, yalnız ouun hatırn için deģil, kamu yararı için de tanınmış olduğu. nu belirtir. Bkz. a.g.e., sh. 13.

${ }^{16}$ Boehmer, a.g.e., sh. 83.

${ }^{17}$ En yeni ve başarılı sayllabilecek Alman örneł̧i için bkz. Dölle, a.g.e., sh. 26-28.
} 
yetleri ayrı iki kișinin hukuken makbul ve geçerli bir şekilde birleşmelerdir» ${ }^{18}$. Schwarz'a göre ise, "Evlilik, tam bir yașama ortaki1* ğına erişmek üzere bir erkekle bir kadın tarafından kurulan ve Devletin hukuk nizammca kabul edilip düzenlenen daimî bir birliktir» ${ }^{19}$. Feyzioğlu evlenmeyi «bir erkekle bir kadının, şekli ve şartları hukuken düzenlenmiş bir akitle, tam bir yaşama ortaklığı yaratmak üzere hayatlarını birleștirmeleri"dir» diye tanımlar ${ }^{20}$. Bu tanımlar çoğaltılabilir. Ancak hepsinin de evlilik birliǧini bir "hayat ortaklığı» olarak kabulde bìrleștikleri görülür. Bu hayat ortaklığından çıkan ahlâkî ve hukukî sonuçlar ${ }^{21}$, gerek özel gerekse kamu hukuku alanlarında yer alan hükümlerle düzenlenir ${ }^{2}$.

Evlilik birliği herșeyden önce manevî bir bağ, ahlâkî temele dayanan bir müessese olmakla beraber, maddî yönü de inkâr ve ihmâl edilemez. Evlilik birliğinin gerçek bir hayat birliği ya da ortaklığı teşkil edebilmesi için, hem manevî hem de iktisadî bir hayat birliği olarak ele alınması gerekir. Bu iktisadî yön tarihin eski dönemlerinden beri açık bir șekilde görülmektedir. Günümüzde de aile, üyelerinin birlikte yeme, içme, giyinme, barınma v.b. gibi ikti. sadî hayatın kullanma ve tüketmeyle ilgili fiillerinin yer aldığı bir müessesesidir. Kısacası aile, üyelerinin ihtiyaçlarını karșılamağa yö nelik bir mal varlığı çevresinde toplanmıştır ${ }^{23}$. Ailenin müşterek ihtiyaçlarn müşterek çalıșma ile giderildiğinden, mal varlığının evlilik birliğinin devamı ve hele sona ermesi halinde tarafların menfaatlerini koruyacak ve aralamnda denge sağlayacak bir biçimde hukukî düzenlemeye tâbi kılmak gerekmiştir. İște böylece karşımıza ailenin malvarlığına ilişkin «mal rejimleri» sorunu çıkmaktadır. Sosyolojik görüşü kuvvetli olan bir hukukçunun isabetle belirttiği üzere, iyi ilișkiler ve barış içersindeki evlilikler için mal rejim. lerine ilişkin düzenlemeler çoğu kez kağıt üzerinde kalır. Çünkü böyle bir durumda, eșler hayatlarının kanunlarını kendileri yapar ve mal rejimleri kurallanın kendileri koyarlar ki, bu genellikle

\footnotetext{
${ }^{18}$ H. V. Velidedeoğlu, Türk Medenî Hukuku, C. II, Aile Hukuku, Istanbuj 1965, sh. 44.

19 A. B. Schwarz, Aile Hukuku (çev. B. Davran) 2. Bası, Istanbul 1946, sh. 27.

${ }^{20}$ N. F. FeyzioğIu, Aile Hukuku Dersleri, Istanbul 1971, sh. 78.

${ }^{21} \mathrm{Bkz}$. Velidedeoğlu, a.g.e., sh. 90.

22 Bkz. Aksoy, a.g.e., sh. 16; S. S. Tekinay, Türk Aile Hukuku, Istanbul 1971, sh. 58 .

z3 Aksoy, a.g.e., sh. 17, 18.
} 
fiilî bir mal ortaklığıdır. Hukukî düzenlemeler ise, yalnızca anlaş. mazlık ve kriz halleri için gereklidir ${ }^{24}$.

\section{§ 3 - Mal Rejinleri. Genel Olarak :}

Ailenin bir iktisadî birlik teşkil etmesi, üyelerinin bakımı ve geçimi konusunda karı kocaya düşen haklar ve görevler, aile birliğinin mâlî hükümlerinin ayrı bir düzenlemeye tâbi tutulmasını gerekli kalmıs, böylece karşımıza kan koca mallarının idare tarzına iliş̧kin çeşitli mal rejimleri çıkmıștır. Evlenmenin eşlerin mallan üzerinde yapacağı etkiler ne kadar önemli bir hukukî sorun ise ${ }^{25}$, evlilik birliğinin boşanma veya ölüm ile sona ermesi halinde, ailenin mal varlığımın eşler yönünden nasıl bir çözüme bağlanacağı da aynı derecede önemli hukukî ve sosyal bir sorun teşkil etmektedir.

Mal rejimleri tarihin çeşitli dönemlerinde ve çeşitli toplumlarda farkh düzenlemelere konu olmuștur. Bugün belli baş̧ı bir kaç tip çevresinde toplanan mal rejimleri, Medenî Kanunumuzun alındığı Isviçre başta olmak üzere, diğer Batı toplumlarında üzerinde titizlikle durulan ve kendisine ayrıntılı hükümler tahsis edilen bir konudur. Ülkemizde modern anlamda bir mal rejimi ancak M.K. nun kabulünden sonra ortaya çıkmıştır. Geçmişe bakacak olursak, eski Türk toplumlarında günümüzdeki mal ayrhlı̆ına benzer bir durumla karșılaşırız ${ }^{26}$. İslâm hukukunda ise tam bir mal aynlığı sistemi görïlür. Karyya kendi mallan üzerinde tam bir tasarruf yetkisi tanınmıştır ${ }^{27}$. Böylece kocanın kan üzerinde sahip olduğu vesayet hakkını kötüye kullanması ve boşanma halinde kadının ik. tisadî durumunun sarsılması önlenmiş oluyordu ${ }^{28}$. Ayrica kadının ev masraflarına katılması zorunluluğu yoktu. Koca karısından hiç bir yardım beklenmeksizin, evin tüm geçimini karşılama durumun. daydı. Mehr müessesesi de karmın iktisaden korunmasında önemli bir rol oynamaktaydı. Mehr, karmmn nikâh akdi ile hak ettiği bir waldır. Yani kocanın evlenme ile karı üzerinde elde ettiği haklara

\footnotetext{
${ }^{24}$ Boehmer, a.g.e., sh. 94.

${ }^{25}$ Velidedeoğlu, a.g.e., sh. 138.

${ }^{26}$ S. M. Arsal, Tiük Tarihi ve Hukuk, I. C, Itstanbul 1947, sh. 33435.

n S. S. Ansay, Hukuk Tarihinde İslâm Hukuku, 2. Bası, I. Kısım Ankara 1954, sh. 177 .

to Bkz. Velidedeoglu, a.g.e., sh. 138.
} 
karşı ona değerli bir şey vermesidir ${ }^{29}$. Amacı, kocanın tek taraflı boşanma hakkına sahip olması nedeniyle, boşanmanın kan aleyhine yaratacağı iktisadî sıkıntıyı azaltmak, onun sefalete düişmesini önlemektir ${ }^{30}$.

\section{A - Türk Medenî Kanununa Göre Mal Rerimleri.}

Görülüyor ki, islâm hukuku ailenin mal varlığı yönünden tek ve zorunlu bir mal rejimi empoze etmektedir. Medenî Kanununmuz ise, Isviçre gibi ortalama bir yol tutarak, eșlere mal varlıklarının akıbetini tayin yönünden sınırlı bir serbesti sistemi tanımıștır. M.K. nun mal rejimlerine ilişkin 170-250. maddelerine göre taraflar dilerlerse, evlenmeden önce veya sonra resmî usûle göre yapacaklar bir "evlenme sözleșmesi» ile «mal birliği» veya «mal ortaklığı»nı akdî rejim olarak tercih edebilirler. Eğer böyle bir sözleş. me yapmamıșlarsa kanunî rejim olan «mal ayrilı̆̆ı" otomatikman işlemeğe başlar. Bunların dışında diledikleri yola gidemiyecekleri gibi, karma bir sisteme de başvuramazlar.

Kanunî rejimin tesbitindeki amaç, çoğu kez tecrübesizliklerinden, çekingenliklerinden ${ }^{31}$ ve özellikle ülkemiz yönüinden, mal rejimlerinden haberdar bulunmadiklarnndan ötürü malî sorunlarla ilgilenmiyen kişileri ve ilerde onlarla çeşitli hukukî ilişkilere girişecek kișileri korumak olarak özetlenebilir.

Kanun koyucumuz kanunî mal rejimini tesbit ederken, mehaz Isviçre M.K. dan ayrılarak, mal birliği yerine, geleneklerimize, da ha doğrusu alışkanlıklarımıza uygun düşen mal ayrılığını kabul etmiştir. Mal ayrhlığının geleneklerimize ve bünyemize uygun düştüğü iddiası, Aksoy'un da belirttiği üzere, tamamen doğru değildir. Çünkü, eski rejimimizde mal ayrılığının zararlarını giderici cihaz ve mehr müesseseleri yer almaktayd ${ }^{32}$. Ayrıca, ilerde göreceğimiz üzere, günümüzün sosyal ve iktisadî șartları yönünden de sosyal adâlet ilkesine aykırı düșmektedir.

\footnotetext{
${ }^{29}$ Ö. N. Bilmen, «Hukuku Islâmiyye ve Istılahatı Fikhıyye» Kamusu, C. II, Istanbul 1950, sh. 30 .

${ }^{30}$ C. Üçok, Türk Hukuk Tarihi, Ankara 1966, sh. 78.

${ }^{31} \mathrm{H}$. Tandoğan, Aile Hukuku Ders Notları (teksir) (Tasnif ve Cüz'ì tlave ler Yapan N. Ayiter) Ankara 1965, sh. 137.

32 Aksoy, a.g.e., sh. 10. Ayrica bkz. Tekinay, a.g.e., sh. 224, 280 d.n. 59.
} 
M.K. mal rejimlerine 70. madde ayırdığı halde, bunlarnn pratik değeri hemen hiç yoktur. Uygulamaya intikâl eden ancak 20 madde civarındadır ${ }^{33}$. Bu durumun nedenleri arasinda, yukanda belirttigimiz üzere, bizde öteden beri karı koca mallarmn idaresi hakkında hüküm bulunmayışı, daha doğru bir deyişle, hukuken dïzenlenmiş tek bir rejime tâbi olma zorunluluğu başta gelir. Bu ne. denle mal ayrılı̆̆ı dışındaki rejimler alışkanlıklarımıza aykırı düş. tüğ̈̈inden ve akdî mal rejimlerinden yararlanma şartları hazırlan. madığından ${ }^{34}$ hakımızca benimsenmemiş bulunmaktadır.

$\mathrm{Bu}$ araştırmamızda çeşitli mal rejimlerini ele almayacağız. Ùzerinde durulması gereken, halkımızın akdî mal rejimlerine çoğu kez bilgisizliği nedeniyle ilgi göstermemesi karşısında, daha da önem kazanan kanunî mal rejiminin yeniden ele alınması ve hayatın gerçeklerine ve ihtiyaçlarına daha iyi cevap verecek şekilde düzenlenmesidir. Baştan ifade edelim ki, mal aynlığının yararlarmı inkâr etmiyoruz. Ancak tarihin belirli dönemlerinde karı yönünden ifa etmiş olduğu müsbet fonksiyonlarının artık yeterli olmadığına, eş. ler arasındaki eşitlik ve dayanışmaya aykırı düştüğüne, evde ya da dışarnda çalışan kadının istismarına yol açtığına, bu nedenle iuzerinde değişiklikler yapılması gerektiğine sözle ve yazı ile değinen meslektaşlarımıza yürekten katılıyoruz ${ }^{35}$.

\section{B - Yabanci Mevzuattaki Gelismeler}

Türkiye için "olması gereken" kanunî mal rejimine geçmeden önce, içersinde yer aldığımız Batı hukuk camiasında bu alanda ortaya çıkan gelişmeleri kısaca gözden geçirmek yararlı olacaktır. Bunun için de kendine özgü bir etki alanına sahip bulunan bir kaç örnek üzerinde duracağız.

Çağımızın modern endüstri toplumlarında değişen hayat şartları ve kadın erkek eşitliği konusunda giderek artan sosyal ve siya. sî baskılarnn gerek kara Avrupa'sı gerek common-law ülkelerinde etkisini göstererek, kanun koyucuları aile birliğinin sosyal ve ik-

\footnotetext{
33 Velidedeoğlu, a.g.e., sh. 139. Mal Or'taklığına ilișkin sözleşmelere de Ege ve Marmara bölgesinde rastlanmış olup, sayısı yirmi civarındadır. Bkz. Tandoğan, a.g.e., sh. 145. Bir davada eşlerin Mal Birliğine tevessül ettik. lerine, ancak sözleșmeyi resmî şekilde yapmadıklarından geçerli kabuł edilmediø̆gne şahit olunmuştur. Bkz. Yt. 2. HD. 29.1.1943, 2339/411 (K. Te. peci, Notlu ve Izahlı Türk Kanunu Medenisi, Ankara 1955, sh. 228).

${ }^{34}$ Feyzioğlu, a.g.e., sh. 187; Aksoy, a.g.e., sh. 10.

${ }^{35}$ Meselâ bkz. Aksoy, a.g.e., sh. 10-11; Tekinay, a.g.e., sh. $280-81$.
} 
tisadî yönü ile yeniden ilgilenmeğe zorladığını belirtmiştik. Böylece bir taraftan karnnm kendi malları üzerindeki tasarruf yetkisi arterllırken, bir yandan da karının koca karşısındaki dûn durumu ted. ricen eşitliğe dünüștürüilmüştür. Eşler arasındaki «dayamışma» ilkesinden hareket eden kanun koyucular, boşanan veya eşi ölen karı. nin malî akıbetini bir sorun olarak ele aldılar. Sonuç olarak, hemen her ülkede karma sistemlere, özellikle eşler arasında dayanışmayı ve evliliğin iktisadî ürünlerinden evde çalışan kadının da yararlanmasını mümkün kılan "kazancan paylaştırlması" ve idare ve tasarrufta eşitlik esasın benimseyen «kazançta ortaklık» yollarına gidilirken ${ }^{36}$, aynı zamanda eşin miras hakkını çoğaltıcı, onu bir numaralı mirasçı durumuna getirici tedbirler üzerinde de durulmağa başland1 ${ }^{37}$.

Bu alanda en ileri adım 1926 yulında Sovyet Aile Hukukunda atılarak, karmın hukukî statüsünün hiç bir şekilde kocadan ve evlenmemiş kadından farklı olamayacağı esasıyla birlikte kazanç ortaklığı sistemi kabul edildi. Karı koca evlilik birliğine getirdikleri mallar üzerinde mal ayrılığı rejiminin bütün hak ve ayrıcalık. larından yararlanacaklar, fakat evlilik süresince kazanlan tüm mal varlığı üzerinde müșterek mülkiyete sahip olacaklardı ${ }^{38}$.

Fransa'da bu süreç çok yavaş cereyan etmiștir. Devrimden sonra Code Civile ile, bu ülkede mal rejimleri alanında hüküm sü. ren kargaşalı̆̆a son verilmiş, kanunî rejim olarak «menkullerde ve kazançta ortaklık» sistemi getirilmiștir. Kadına akitler alanında serbestî tanınmıșsa da, hukukî yetkiler bakımından kocaya tâbi kı. lınmış; kocanın aile malları izzerindeki tasarruf yetkisi alabildiğine korunmuştur ${ }^{39}$. Ancak endïstrileşmenin etkisiyle, önce kocanın karısının gayrımenkulleri üzerindeki yetkileri giderek azalmıs, daha sonra da kadınların çalışmaları genelleșince, 20. yüzyılın başların. da girişilen reformlarla karının ücreti ve tasarrufları üzerindeki

\footnotetext{
36 Aksoy, a.g.e., sh. 11.

3 Aksoy, a.g.e., sh. 9-10.

38 W. Friedmann, Law in a Changing Society, Los Angeles and Berkeley, 1959, sh. 240.

${ }^{39}$ M. Desbois, «France», (La Regime Matrimonial Légal dans Ies Législations Contemporaines, sous la direction de A. Rouast - J. B. Herzog; I. Zajtay, Paris 1957) sh. 181; M. Ancel, «Matrimonial Property Law in France», (Matrimonial Property Law, Ed. by W. Friedmann, London 1955) sh. $6-7,13$.
} 
haklarına son verilmiștir ${ }^{*}$. Böylece karn kendi üceretinin ve biriktirimlerinin sahibi olurken, kocanın herhangi bir nedenle normal idare yetkisini kullanamıyacak duruma düştüğui hallerde, aile birliğini temsil yetkisini de kazanmıștır ${ }^{* 1}$.

Fransa'da kadının bağımsızlığa kavuşmasında feminist akımlardan çok kadınların çalışması, özellikle I. ve II. Cihan Savașlanında, erkeklerden boşalan iş alanlarında varlık göstermeleri rol oynamıștır. Böylece 1938 ve 1942 tarihlerinde kabul edilen kanunlarla karmın hukukî bağımlılı̆ı̆na son verilmiş, nihayet yeni mevzuat, artık Napoleon'un zamanındakinden çok farklı olan modern ailedeki eșlerin ilişsilerine ayak uydurma yoluna girmiștir. II. Cihan Savaşından sonra yepyeni bir Medenî Kanun yapılması fikri üzerinde durulurken, evli kadının durumu da yeniden ele alındı. 7 Haziran 1945 de kurulan Komisyon çalışmalarına büyük bir istek. le bașladı ise de, umulan sonuç alınamadı. Nihavet Code Civile'nin tamamen değiștirilmesi fikrinden vaz geçildi ${ }^{42}$. Ancak mal rejimlerine iliş̧kin çalışmalara ara verilmedi. Değişen sosyal şartları ve or. taya çıkan yeni fikirleri değerlendiren Komisyon, «karının aile mallarının idaresine katılması imkânlarının çoğaltılması», «koca. nin evlilik mallan üzerindeki idare yetkisinin daraltılması" ve "kadına evlilik süresince kazanılan tüm mallar üzerinden pay tanın. ması" konuları üzerinde durdu ${ }^{43}$. Nihayet 13.7 .1965 de kabul edilip 1.2.1966 da yürürlüğe giren mal rejimlerine iliş̧kin Kanun karıyı kocaya hukuken eşit kılarken, kanunî mal rejimi olarak ta «kazançta ortaklık» sistemini getirdi *.

Yeni kanunî rejimde üç malvarlı̆̆ grubu vardır: a) Karnnın şahsî mallan, b) Kocanın şahsî malları ve c) Ortaklık malları ki, karı ve koca tarafından evlilik süresince kazanılmıs tüm menkûl ve gayrımenkûlleri ihtiva etmektedir (md. 1401). Karı ve Koca kendi şahsî malları üzerinde tasarruf ve idare yetkisine ayrı ayrı sahiptirler (md. 1428). Oysa, eski rejimde, karmın şahsî mallarının ida-

\footnotetext{
* Bu konuda çıkanlan kanunlar için bkz. Ancel, a.g.m., sh. 7. Her alanda olduğu gibi bu alanda da kanun koyucuların toplumdaki gelişmeleri eninde sonunda izlemek zorunda kalışlarına ilişkin ilginç örnek için bkz. H. Topçuoğlu, Hukuk Sosyolojisi (Teksir) Ankara 1972-73, sh. 28-29.

41 Ancel, a.g.m. sh. 7.8 .

${ }^{42} \mathrm{M}$. Ferid, Das Französische Zivilrecht, Erster Band, Frankfurt am Maine, Berlin 1971, sh. 135.

43 Aksoy, ag.e.,sh. 215; Ancel, a.g.m., sh. 26-28.

4 S. Boschan, a.g.e., sh. 139.
} 
resi de kocaya aitti. Ortaklık mallarının idaresi kocaya bırakılmıştır (md. 1421). Ancak bu hususta kendisine sorumluluklar yüklenerek, ortaklık malarının mutlak hâkimi ve idarecisi olmaktan çkarılmıştır. Menkûller uizerindeki tasarruf yetkisi tam olmakla beraber, gayrımenkûllerin ve ticarî senetlerin satışı, temliki gibi önemli muamelelerde karmın rızasın alma zorundadır (md. 1424) ${ }^{45}$.

Kazanç Ortaklığı aile birliğinin sona ermesi ile etkilerini göstermeğe bașlar; karının haklan fiilî bir durum kazanır, yani ortaklık malları iki eș arasında (evlilik ölüm ile sona ermişse, ölenin mirasçları ile să̆ kalan eş arasında) bölüştürüüür ${ }^{46}$.

Dünya kamu oyunun takdirle karşıladığı Alman kanunî mal rejimi «artmış kazançta ortaklık» (Zugewinngemeinschaft) yeni bulunmuș bir müiessese değildir. Artmış kazançta ortaklık 1900 yılın. dan önce Almanya'nın bazı bölgelerinde ve ZGB nin kabulïnden önce bazı Isviçre kantonlarında uygulanmaktaydı. Ayrica bu rejim 1901-1914 tarihleri arasında Macaristan'da hazırlanan tasartlarda da yer almıș, kanunlaşmamıșsa da mal reijmlerinin düzenlenmesinde etkili olmuştur ${ }^{47}$.

Almanya'da Medenî Kanun tasarisının yayınlanmasından hemen sonra, tasarının ortaya koyduğ mal rejiminin âdalete, kadlnın menfaatlerine aykırı düștüğü, zamanın hukuk ve evlilik kavramlan ile bağdașmaz olduğu ileri sürülmüștür ${ }^{48}$. 1950lerden sonra da bașta Boehmer, Dölle gibi ünlü hukukçular, yüksek hâkimler, sosyologlar, siyaset adamları ve partiler aynı görüște birleșmişlerdir *. Tartışmalar, eleștiriler ve savunmalar nihayet ürününü vermekte gecikmedi. Yeni Bonn Anayasası md. 3/2 de kadın erkek eșitliğini açıkça beyan etmekle kalmıyor, md. 117/1 de bu eşitlik ilkesine aykırı bulunan herhangi bir kanun hükmünün ancak 31 Mart 1953 tarahine kadar yürürlükte kalabileceğini ifade ediyordu. O tarihlerde karının getirdiği mallar üzerinde kocanın idare ve intifa hakkını tanıan mal rejimi Anayasanın eşitlik ilkesine aykım

45 J. Carbonnier, Droit Civile, Tome 2, Paris 1969, sh. 99.100.

46 Carbonnier, a.g.e., sh. 101.

47 Dölle, a.g.e., sh. 736-738; A. N. Inan, Erkek Kadın Hukukî Müisavatı Alman Aile Hukukunda Ne Gibi Deł̧işiklikler Yapacak ve Bu Değişiklikleri içine alan 2. Kanun Tasarısının Hükümleri, AD, 1956, S. 8, sh. 823 d.n. 32.

48 Bkz. F. Masfeller, «Matrimonial Propert Law in Germany» (Matrimonial Property Law), sh. 388; Aksoy, a.g.e., sh. 127; Boehmer, a.g.e., sh. 92 v.d.

4 Inan, a.g.m., sh. 823; Aksoy, a.g.e., sh. 128-129; Masfeller, a.g.m., sh. 388. 
düştiŭgünden, 117. madde gereǧince 31 Mart 1953 tarihinden itibaren yürürlükten kalkmış yerine, bir bakıma mal rejimi yokluğu demek olan, mal ayrılığı sistemi geçmiştir ${ }^{s 1}$. Bu arada başlayan reform çalışmaları șu noktalar üzerinde temerküz etti : Anayasanın md. 3/2 gereğince kan, kocanın vesayetinden kurtulmalydı. Kadınlar, dünyanın diğer yerlerinde olduğu gibi çalıșmak, aile bütçesine yardımda bulunmak zorunda idiler. O siralarda Alman kadınlannın büyük bir kısmı kendilerini ev işlerine ,çocuklarının yetiştirilmesine hasretmekte, bu arada kocalarının işlerine de yardım etmekteydiler. Iște bu kadınların kendi hesaplarnna bir kazanç sahibi olmaları söz konusu değildi. Evlilik birliği boșanma veya ölüm ile sona erdiğinde, bu kadınların durumunu iktisaden koruyacak yeterli kanun hükümleri yoktu. Oysa onlar, yalnız ev işleri görmekle da. hi, kocanın kazancına katkıda bulunuyorlardı. Bu nedenle aile mallarının karı koca arasında eșit olarak paylaştırılması gerekiyordu ${ }^{51}$. Nihayet 8 Haziran 1957 tarihli «Kadın Erkek Eșitliği Hakkında Kanun» (Gezetz über die Gleichberechtigung von Mann und (Frau) "Artmış Kazançta Ortaklık»ı kanunî mal rejimi olarak beyan etti ${ }^{2}$. Eșlerin evlilik süresinde ortaklaşa çalışmalarının sağladığı ürünlerin onlar arasında paylaştırılmasını esas alan bu rejim, ağıırlık nok. tasını evlilik birliğinin sona ermesine aktarnyordu. Şöyle ki : Evlenmekle, «Kocanın ve karmın malları eșlerin ortak malı haline gelmez; bu durum eşlerden birinin evliliğin akdedilmesinden sonra kazandığı mallar için de aynıdır. Ancak eşlerin evlilik süresinde sağladıkları artmıș kazanç (Zugewinn), ortaklığın sona ermesi ha. linde paylaștırılır» (BGB § 1363/II). "Artmış kazanç" ise, "eşlerden her birinin evlenmenin sona erdiği sıradaki malvarlı̆̆ının, evienmenin başlangıçtaki malvarlı̆̆ını aşan kısmıdır» (BGB § 1373). Öte yandan «Eşlerden birinin artmış kazancı diğerininkinden fazla ise, dił̌er eș bu fazlalığın yarısı üzerinde denkleștirme talebine hak kazanır» (BGB § 1378) ${ }^{53}$. Görüldüğ̈̈̈ üzere, evlilik süresince eşler kendi malları üzerinde serbestçe tasarruf yetkisine sahip bu. lunuyorlar. Ancak bu haklarını kötüye kullanmaları, meselâ israfa gitmeleri kanunun öngördüğü hükümlerle yasaklanmış, böylece «diğer eşin sahip olduğu kazancın denkleștirilmesi hakkı» gereğince

\footnotetext{
${ }^{50}$ Masfeller, a.g.m., sh. 376-77; Dölle, a.g.e., sh. 733-34.

s1 Masfeller, a.g.m., sh. 377 v.d.

\$z Dölle, a.g.e., sh. 734; Boehmer, a.g.e., sh. 92; G. Scheffler - H. Koeniger,

Das Bürgerliche Gesetzbuch, IV. Band, 1. Teil, Berlin 1960, sh. 88 Anm. 45.

${ }^{53}$ Scheffler-Koeniger, a.g.e., sh. 165, Anm. 3.
} 
korunmuştur (BGB $\S 1365, \S 1369$ ) ${ }^{\text {s4 }}$. Öte yandan, evlilik süresince eşlerden birine miras yoluyla geçmiş bulunan, bağış veya hediye olarak verilmiş kazançlar, haklı olarak paylaşma dışı bırakılmış. tir (BGB § 1374/II) ${ }^{55}$.

Karının iktisaden korunması konusunda çok ileri gitmiş olan Isveç'e gelince, 1734 tarihli Kanuna göre eşlerin malları evlenme ile bir bütün teşkil etmekte ve koca tarafindan idare edilmekteydi. 1874 de karıya malların idaresinde belirli haklar tanındrysa da, koca bütün malların idaresinde söz sahibi bırakılmıștır. 19. yüzyılın ikinci yarısında ileri sürülen reform teklifleri nihayet 11.61920 yilında Evlenme kanunu (Giftermâlsbalken) ile gerçekleşmiştir. Bu kanuna göre, karı kocanı aile birliğine getirdikleri mallar üzerindeki mülkiyet ve idare hakkı kendilerine aittir. Fakat evliliğin sona ermesi halinde, bazı hediyeler ve ayıı (mahfuz) sayılan mallar dışında, evlilik süresince edinilen mallar da dahil olmak üzere, tüm aile malları eşler arasında eşit olarak paylașılacaktır ${ }^{56}$. Böylece kanun koyucu kocanın eski hâkimiyetine son vermekte ve eșlere malî yönden bağımsızlık tanımaktadır. Ancak «evlilik birliği» fikrini destek. lemek üzere, eşlerden herbirine diğer eşin sahip bulunduğu ve evli. lik süresince sahip olacağı mallar iuzerinde «es payı (giftoraetti) adı verilen bir hak bahședilmektedir ${ }^{57}$. Bağımsızlık ilkesinin zedelenmemesi için, eşlerden birisinin mallarının idaresini diğerine tamamen bırakması da yaisaklanmıștır ${ }^{58}$. Gene kanunun öngördüğü malî bağımsızlık ilkesi nedeniyle, karı koca kendi borçlarından ay. n ayr sorumludurlar. Ancak bu, özellikle aile harcamaları yönün. den, birlikte sorumlu olabilmelerini engellemez ${ }^{59}$.

Eşlerden birisinin ölümü halinde, belli mallar dıșındaki tüm mallar bir ortaklık teşkil eder ve geride kalan eş bu malların yarısına sahip olur. Diğer yarı hakkında miras hükümleri câri olur ve sağ kalan eş bu kez kanunî mirasçı olarak karşımıza çıkar ${ }^{60}$.

\footnotetext{
54 Dölle, a.g.e., sh. 749 v.d.

ss Scheffler-Koeniger, a.g.e., sh. 167, sh. 168-69, Anm. 5.

${ }^{56} \mathrm{Bu}$ esas Danimarka, Finlandiya, Izlanda ve Norveç'te de büyük ölçüde benimsenmiștir. Bkz. A. Malmström, Matrimonial Property Law in Sweden (Matrimonial Property Law), sh. 411; Friedman, Law in a Changing Society, sh, 242.

57 Malmström, a.g.m, sh, 410-411, 413 v.d.

58 Malmström, a.g.m., sh. 415.

s9 Malmström, a.g.m., sh. 416-17.

${ }^{60}$ Aksoy, a.g.e., sh. 115; Malmström, a.g.m., sh. 427-28.
} 
Anglo-saxon ülkelerine gelince, 19 . ve hattâ 20 . yüzyl mevzuatı mal rejimlerini düzenlerken, erkeğin üstünlüğ̈ünü belirliyordu. Genel kanı, evlenme ile karı kocanın bir bütün, yani aile birlibu bütün içersinde erkeğin başlı başına bir bütün, yani aile birliğinin her yönden tek hâkimi ve efendisi olduğu merkezindeydi. Kocanın karısının malları üzerindeki hâkimiyet hakkını istismar etmesini önlemek üzere, nısfet hukuku (equity law) common law'dan uzaklaşarak, "ayrılmıs mal» (seperate estate) kavramını ortaya atmıștır. Şöyle ki, 19. yüzyılın sonlarına doğru Ingiltere'de varlıklı sınuflardan bir kız evlenirken, babası nısfet hukukundan yararlana. rak, özel bir sözleşme ile (statements) onun lehine kocasının müdahale edemiyeci bir takım mallar tahsis ediyor, karı da bu mallar üzerinde dilediği gibi tasarrufta bulunabiliyordu. Başlangıçta ancak varlıklı sinfflara ait olan bu imtiyaz, endüstrinin gelișmesi, kadınların dışanda çalışması, liberalizm akımı ve feminist hareketlerin etkisiyle genelliști. Reform yapma gereğini idrak eden Par. lâmento 1882 tarihli «Married Women's Property Act» ile bugün de büyük ölçüde geçerli olan "mal ayrılığı" sistemini getirdi ${ }^{\circledR 1}$. Ancak bu kanun ile kadın erkek eşitliği sağlanamadığı gibi, mal ayrulığının karı aleyhine olan yönleri sürekli şikayet konusu teșkil etmekteydi ${ }^{62}$. Nihayet 1935 tarihli «Married Women and Tortfeasors Act» ile karı kocanın gerek özel hukuk gerek usûl hukuku yönünden eşitliği, borçlardan ise ayrı ayrı sorumlu olmaları esası getiril$\mathrm{di}^{63}$. Ayrıca miras hukukuna baş vurularak' 1925 tarihli "Administration of Estates Act» ve 1952 tarihli «Intestates' Estates Act» ile mal ayrılığının karı aleyhine olan sonuçları büyük ölçüde gideril$\mathrm{di}^{64}$.-

Ingiltere'de reform çalıșmaları sona ermiş değildir. Meselâ «Royal Comission on Marriage and Divorce» 1955 Aralık ayında hazırladığı raporda mal rejimleri üzerinde özellikle durarak, ev kadınlarının kocalan karşısındaki iktisadî durumlannın düzeltilmesi, yani kannın kocanın kazancma katılması sorununu ele almış ${ }^{65}$, kazanç ortaklığı tekliflerini görmüşstür. Bugün de mal rejiminin değişen hayat şartları karșısında, diğer ülkelerin tecrübele

\footnotetext{
${ }^{61}$ D. Kahn-Freund, "Matrimonial Property Law in England» (Matrimonial Proferty Law), sh. 273-76; H. Hanish, Moderne Tendenzen der Englischen Ehegüterrechts, Berlin 1963, sh. 17.

${ }^{62} \mathrm{Kahn-Freund,} \mathrm{a.g.m.,} \mathrm{sh.} 281$.

${ }^{63} \mathrm{Kahn}$-Freund, a.g.m., sh. 286 v.d.

${ }^{64}$ Kahn-Freund, a.g.m., sh. 284-86; Hanish, a.g.e., sh. 85 , 86.

${ }^{65}$ Hanish, a.g.e., sh. 105-106.
} 
rinden de yararlanılarak, reforma tâbi tutulması gereği ısrarla savunulmaktadir ${ }^{6}$.

\section{C - Türkiye Yönünden Yeni Bir Kanunî Mal Rejimine Duyu- lan Ihtiyaç.}

Bizde kanunî mal rejiminin mal ayrıhı̆̆ olduğunu belirtmiştik. Buna göre eşlerden herbiri kendi mallarmun mülkiyet, idare ve intifaına sahiptirler (M.K. md. 186). Mallarının geliri ve kazançları da kendilerine aittir (md. 189). Evi geçindirme görevi kocaya düşmekle beraber, karıdan aile masraflaruna münasip bir oranda katılmasinı isteyebilir (md. 190/1).

Koca kendi şahsî borçlarından, evlilik birliğini temsilen yapt1ğ borçlardan ve karının evlilik birliğini temsilen yaptığ borçlardan şahsen sorumludur (md. 187/1). Karı da kendisinin ve kocasının evlilik birliğini temsilen yaptığı borçlardan, kocasının aczi halinde ikinci derecede sorumludur (md. 187/2). Karı, kocanın aile harcamaları dışındaki borçlarından ikinci derecede dahi sorumlu değildir. Buna karşılık kendisinin aile masraflarından saylmayan borçları için şahsen sorumludur.

Mal ayrılığında esas, malların idaresinin de ayrı olmasıdır. Ancak karı mallarının yönetimini kocaya bırakabilir (md. 186/2). Bu durumda karı koca arasında bir çeșit vekâlet ilișkisi doğar ${ }^{67}$ ve karmm evliliğin devamı süresince kocadan hesap sormaktan vaz. geçtiği veya mallarının bütün gelirini ev masraflarına karșılık olarak kocaya bıraktığı farzedilir. Karı, kocaya devrettiłi bu idare hakkını her zaman için geri alabilir (md. 186/3). Ancak karı, mallarının idaresini kocaya bırakmış bile o!́sá, kocanın iflâsı veya aleyhine haciz konması halinde, imtiyazlı bir alacaklı durumuna geçe. mez (md. 188). Boşanma halinde ise, karı koca kendi șahsî mallanni geri alır (md. 146).

Esaslarını kısaca görmüș olduğumuz mal ayrılı̆̆ı rejimi kökï eski Türklere kadar uzandığı, islâm hukukunun yarattığı gelenĕge uygunluğu, uygulamadaki basitliği, karıya daha bağımsız bir durum kazandırdığı ve eşlerin malî ilişkileri bakımından üçüncüi şahıslara karșı açıklık getirdiği için savunulmaktadır ${ }^{68}$. Fakat son

\footnotetext{
66 Friedmann, a.g.e., sh. 244-45, Geniş Bilgi için bkz. Hanish, a.g.e., sh. 115 v.d.

${ }^{67}$ Tandoğan, a.g.e., sh. 140; Velidedeoğlu, a.g.e., sh. 151.

68 Bkz. Velidedeoğlu, a.g.e., sh. 147; Feyzioğlu, a.g.e., sh. 199.
} 
yıllarda mal ayrilı̆̆ına karșı tepkiler ve eleștiriler hukuk literatüründe yer almağa başlamıştır ${ }^{69}$. Şurası bir gerçektir ki, bu rejim karının bağımsızlığını kazanmasında büyük ölçüde hizmet etmiştir. Ancak günümüzdeki sosyal değișmeler nedeniyle, artık kadının aleyhine işleyen bir müessese haline gelmiștir.

Montesquieu'nun isabetle belirttiği gibi, iyi bir kanun koyucu başka bir ülkenin kanununu iktibas ederken, kendi toplumunun özelliklerine dikkat edecek, örf-âdetine tamamen yabancı ve aykır olmamasını sağlayacaktır. Türk kanun koyucusu da bu gerekçeden hareketle, kanunî mal rejimi olarak mal ayrılığının toplumsal yapımıza, geleneklerimize uygun düștügü kanaatiyle hareket etmiștir. Ancak bu gerekçe günümüzde geçerliğini yitirmiş bulunmaktadır. Şöyle ki : 20. yüzyllın ikinci yarısından sonra güç kazanan feminist akm, eşitlik ilkesi ve özellikle II. Cihan Savaşından sonra ürünlerini veren "iktisaden zayıf durumda bulunanların korunması" ilkesi ve nihayet giderek gelişen sosyal hukuk devleti anlayışı ülkemizde de etkisini göstermiş, bu alandaki hükümlerin Anayasada yer almasına yol açmıștrr. Öte yandan sosyal ve iktisadî alandaki değişmelerin sonucu, kadınlarımız artan bir oranda çalıșma hayatma atılmaktadırlar. Ülkemizde çalıșan kadınların erkeklere oranı $\% 38$ e ulaşmıștır. Bu yüzdenin büyük bir kısmını da kırsal bölgelerde, tarım alanında çalışan kadınlarımız teşkil etmektedir ${ }^{n 1}$. Büyük kentlerde ise hayat pahalılı̆̆ı kadınların çalışmasını zorunlu kılmaktadır. Bu bakımdan kadının aile bütçesine katkısı ve aynı zamanda sorumluluğu da artmaktadır. Çalışan kadın bir yandan iş yerinde başarılı olmak, diğer yandan da çalıșmadan arta kalan zamanını, hizmetçi ücretlerinin artronomik rakamlara yükselmesi nedeniyle, ev işlerine, kocasının ve çocuklarımın bakımına hasretmek zorundadır. Ev kadını ise, dışarda çalıșıp şahsî bir gelirse sahip olma yerine, tüm çabasını aileye yöneltmiș, dolayısiyle kocasına des. tek olmuştur. Öte yandan boşanmalar ciddì bir sorun teşkil etme yolundadır ${ }^{71}$. Nafaka hükümlerinin yetersizliği nedeniyle, kadını iktisadî durumunun korunması önem kazanmaktadır. Varlıksız kadınların sokağa düșme ya da akrabalarının yanında sığıntı olma korkusuyla, her yönden iflâs etmiş evlilikleri sürdürmede diren-

${ }^{69}$ Bkz. Tekinay, a.g.e., sh. 281; Aksoy, a.g.e.,

${ }^{70}$ A. Kurtkan, Köy Sosyolojisi, Istanbul 1968, sh. 132.

711946 yılında boşananlarnn sayısı 6373 iken, bu sayı 1966 da 22033 e ulaşa rak dört misli artmıștır. İstatistik Yıllığı 1951 C. 21. Adalet İstatistikleri $1960-67$. 
melerinin nedeni işte burada yatmaktadır. Çoğukez kadının çalışması ile ailenin malvarlı̆̆ında ortaya çıkan artışlar, ataerkil aile geleneklerinin esası olan erkek egoizmi ve gururu nedeniyle, kocaya ait olmaktadır. Gayrımenkuller kocanın adina tapuya kaydol. makta, kıymetli ev eşyalarımı faturaları kocamın adına çıkartılmaktadır. Hele kocanın tarlasınsa boğaz tokluğuna çalışarak, bütün gençliğini harcayan köylü kadın, «boşanma halinde koca evini beş parası terkedip gitmekte» veya kocasun daha genç ve dinç bir kadınla paylaşmak zilletine katlanmakta, «bu da mal ayrılığı sistemimizin güya geleneklerimize uygun olan bir sonucunu teşkil etmektedir» $\pi$.

Velidedeoğlu'nun «M.K., kan koca arasında kanunî mal sistemini 'mal ayrılığı' olarak kabul etmekle Türk kadınının hukukî durumunu, İsviçre kadınınkinden daha müsait bir hale koymuştur ${ }^{73}$ iddiası, bugünkü koşullar altında geçerliliğinden çok şeyler kaybetmiştir. Çünkü mal ayrılığı, ailenin manevî birliğini iktisadî bir birlik olmaktan uzaklaştırmakta, boşanma veya ölüm halinde, diğer eşin sanki ortak malların yaratıcısı değilmiş gibi muamele görmesine yol açmaktadır. Bu durumda artık kanunî rejimi değiştirmek ya da zararlarını giderici tedbirler almak zaman gelmiştir. Bazı meslekdaşlarımız «mal ontaklı̆gını kanunî rejim olarak önermektedirler. Mal ortaklı̆̆ı, ekonomik birliğin eşler arasından tam olarak kurulmuș bulunması nedeniyle görünüişte idealdir. Ancak karının ortak mallar üzerinde yönetim hakkı olmaması ve kocanın fiiliyle ortaya çıacak zararlardan kararının da sorumlu kılınması, bu rejimin en başta gelen kusurudur. Ayrica evlenme anında var. lıklı olan ve bu varlığı miras, hibe yoluyla artmış bulunan eș, bunlan diğer eşi ile paylaşmak zorundadır. Ancak evlenmenin sona ermesi halindeki taksim, diğer eşi malî yönden büyük ölçüde koruduğu için, gene de mal ayrılhğından üstündür.

Bizim kanımızca kanunî mal rejiminin «kadının bağımsızlığı ve erkekle hukukî eşitliği» ilkesi ile "ailede dayanışmanın gerçekleştirilmesi» ilkessini bağdaştıracak biçimde düzenlenmesi gerekmektedir. Bunun için bir yandan ilk ilkeyi gerçekleştirecek ve geleneklerimize aykırı dìşmeyecek mal ayrılığın muhafaza ederken, ikinci ilkeye ve sosyal adalet anlayışına cevap verecek olan «evlilik birliğinin sona ermesi halinde artan kazancın paylaştırnlması» esa-

72 Tekinay, a.g.e., sh. 280.

7 Velidedeoğlu, a.g.e., sh. 139. 
sun da kabul ederek, karma bir sisteme gitmek, en çıkar yol ola. rak gözükmektedir.

\section{§ 4 - Boşanmanm İktisadî Somuçlarma Karșı Karunun Korunması:}

Yukarıda görmüş olduğumuz üzere, modern mevzuat karma mal rejimi sistemlerine giderken, karmmn evliliğin iktisadî ürünlerinden yararlanmasını sağlamak, böylece boşanma halinde varlıksız eșin sıkıntıya düsşmesini önlemekle kalmamıs,, onu ayrıca nafaka ile de desteklemiștir. Bu alanda çok ileri giden İsveç'te son yıllarda yapılan değișiklik ile, daha önce boşanmıș eş lehine nafakaya hükmolunabilmektedir. Yani boşanmış eş, daha önce nafaka talebinde bulunmamış bile olsa, durumu gerektirdiğinde nafaka davası açabilmektedir. Ayrıca hayat şartlarının değişmesi halinde, hük. molunan nafakanın miktarı çoğaltılabilinmektedir. Öte yandan eşlerden biri, boşanmadan önce oturulan ortak konuta şiddetle muhtaç ise, bu konut ister diğer eşin mülkiyetinde olsun ister onun tarafından kiralanmıș bulunsun, mahkeme kararıyla kendisine tahsis edilebilir ${ }^{74}$.

Benzer bir duruma Ingiltere'de de rastlanmaktadır. Ingiliz Temyiz Mahkemesi, özelikkle kocası tarafından terkedilen kadına aile mallarını bir kısmı izzerinde hak tanyan yeni bir nısfet hukuku (equity law) geliştirmiştir. Bendall v. McWhirter (1952, 2 Q. B. 466) davasında ve bunu izleyen davalarda karıya ailenin ikametgâhını, muilkiyeti kocaya ait te olsa, işgal yetkisi tanunmıştır. Rimmer v. Rimmer ve benzeri davalarda ise, evlilik süresince karı kocanın ortaklaşa katkısıyla edinilen mallarda, meselâ bir evin satın alınmasında, eşlerin katkı oranları kesinlikle tesbit edilmese bile, eșlerin paylarının yarı yarı olacă̆ı̆ hükme bağlanmıștı. ${ }^{75}$ Bundan başka mal aymlı̆̆ının boșanma nedeniyle karı aleyhine yaratacăğı sonuçlar da nafaka ile hafifletilmektedir. Hâkim takdir hakkına dayanarak, kusuru olsun veya olmasın, kocayı süreli ya da süresiz olarak karıya nafaka ödemeğe mahkûm edebilmektedir.?.

Modern mevzuat, boșanmada kusursuz ya da kusuru diğerine oranla az olan eşe (ki bu genellikle karıdır), geçimini kendi geliri

\footnotetext{
${ }^{74}$ Aksoy, a.g.e., sh. 120-21.

${ }^{75}$ Burada hâkim olan fikir, karının dışarıda çalışmasa bile, çocukların eğj. timini, evin idaresini derthte etmesi nedeniyle, aile bütçesine katkıda bulunmakta oldư̆udur. Bkz. Friedmann, a.g.e., sh. 243-44.

${ }^{75}$ Hanish, a.g.e., sh. 80-82; Kahn-Freund, a.g.m., sh. 309.
} 
veya çalışması ile karşılayamaması halinde, nafaka talep etme hakkını tanımakta; nafakanm süresini de bu ihtiyaç halinin devami ile sinırlamaktadır. ${ }^{~ N a f a k a ~ b o r c u ~ n o r m a l ~ o l a r a k ~ e s ̧ l e r d e n ~ b i . ~}$ rinin ölümü ile sona ermekte ise de, Alman kanun koyucusu bu alanda da ileri bir adım atmış, nafaka borçlusunun ölüimü halinde, nafaka alacaklısına, ölenin mirasçlarına yöneltilen "terckeye bağl bir alacak hakkı» tanımıștır. ${ }^{78}$

Ülkemizde boșanan eșin (ki bu normal olarak karıdır) iktisaden korunması konusunda karşmıza «tazminat» ve «yoksuliuk nafakası» müesseseleri çıkmaktadır.

\section{A. Tazminat}

M.K. boşanmadan zarar gören kabahatsiz eşi korumak üzere B.K. nun haksız fiillere ilişkin genel hükümlerinden ayrı olarak, maddî ve manevî tazminata ${ }^{79}$ yer vermiștir. Md. 143 e göre, "Mevcut ve hattâ muntazar bir menfaatı boşanma yüzünden haleldar olan kabahatsız karı veya kocamın kabahatlı olan taraftan münasip bir maddî tazminat talebine hakkı vardır. Bundan başka boşan. maya sebebiyet vermiş olan hadiseler kabahatsız karı veya kocanın şahsî menfaatlerini ağır bir surette haleldâr etmiş ise, hâkim manevî tazminat nâmı ile muayyen bir meblağ dahi hükmedebilir.»

Kanunda hüküm olmamakla beraber, Yargıtay maddî veya manevî tazminat taleplerinin boșanma davsı ile birlikte görülebileceğini, boşanma kararı verildikten sonra ayrı bir dava ile tazminat istenemiyeceğini içtihat etmiştir. ${ }^{\$ 0}$ Yargitayın bu tutumu sakattır. Çünkü boşanma kararından sonra kabahatsız olduğunu, tazminat talebine hakkı. bulunduğunu anlayan eș, artık hiç bir şey yapamayacaktir. ${ }^{81}$

${ }^{77}$ Almanya için bkz. Dölle, a.g.e., sh. 600 v.d.; Fransa için bkz. Carbonnier, a.g.e., sh. 149.

${ }^{78}$ Dölle, a.g.e., sh. 618.

${ }^{79}$ Maddî ve manevî tazminat hakkında ayrıntılı bilgi içiı bkz. H. K. Eibir, Bosanma Halinde Maddî ve Manevî Tazminat ve Nafaka Haklarmun Toplu bir Tetkiki, Ist. Bar Der. 1948, S. 1; T. Esener, Boşanmadan Mütevel. lit Maddî ve Maneví Zararın Tazmini Ne Zamana Kadar Talep Ecille bi. lir? AHFD 1951, C. VIII, S. 1-2.

* Meselá bkz. Yt. 2. HD. 26.9.1969, 4219/4248 (Yazıcı-Atasoy, Şahıs Aile ve Miras Hukukunda Yargitay Tatbikatı, 1952.1970, Ankara 1970), No. 650.

"1 Esener, a.g.m., sh. 656-57. 
Medenî Kanun Öntasarısı bu alanda daha gerçekçi davranarak, sözü geçen maddede değişiklik yapmıştır. Şöyle ki :

"Mad. 143 - Boşanmada kusuru olmayan veya kusuru ötekine kıyasla hafif olan eşin mevcut veya beklenen malî haklan boşanma yüzünden zarara uğrarsa, kusurlu eş ona uygun bir maddî tazminat ödemekle yükümlüdür.

Eşlerden hiçbirinin kusuru yoksa, hakkaniyet gerektirdiği takdirde yargıç, boşanma yüzünden zarar gören eşin istemi üzerine, ona öteki eş tarafından uygun bir maddî tazminat ödenmesine karar verebilir.

Kusuru olmayan veya kusuru ötekine kryasla daha az olan eşin kişilik haklan boşanmaya sebep olan olaylar yüzünden ağır surette zedelenmişse, kusurlu eş ona, uygun bir manevî tazminat ödemekle yükümlüdür.

Maddî veya manevî tazminat istemi varsa, tazminatın miktarı taraflar arasında serbestçe tayin olunabilir ve bu miktar mahkemece karara bağlanır; taraflar uzlaşamazlarsa bu miktarı doğrudan doğruya mahkeme tayin ederek karara bağlar.

Maddî veya manevî tazminat, boşanma davası görülürken da vanın her safhasında istenebileceği gibi, boşanmadan sonra açlacak bir dava ile de istenebilir; ancak boşanma kararının kesinleştiği tarihten bir yıl geçmekle dava hakkı düşer.»

Bu maddenin gerekçesinde ifade edildiği üzere, boşanmanın kolaylaştırılması nedeniyle, bundan en çok zarar görecek kişinin karı olacağı açıktır. Bu nedenle malî yönden uğrayacağı zarar hesaba katılmalıdır. Şu halde eş (karı) diğerine oranla daha az kusurlu ve hattâ her ikisi de kusursuz olsa bile, hakkaniyetin gerektirdiği durumlarda maddî ve manevî tazminata müstahak olmall. dır. Yeni madde ile eşler tazminatın miktarnn serbestçe tayin ede. bileceklerdir. «Buna karş1 denebilir ki : Tazminat ödenmek suretiyle karşılıklı rızaya dayanan boşanma yolunun dolambaçlı olarak yasaya konulması sakıncalıdır. Oysa... ayakta durmasına imkân olmayan bir evlilik birliğinin zorla yürütülmesine ugraşmaktansa, zarar gören tarafın ve özellikle kadının zararlarının tazmin ettirilmesi suretiyle boşanmaya imkân verilmesi gerek ailenin ve gerek toplumun yararnadır. Bu hususta suistimaller olabileceği

ga Medenî Kanun Ontasarısı, sh. 135-36. 
düşüncesi de yerinde olmaz; zira yasa hükümlerin kötüye kullanmak isteyenlerce yalnuz boşanma kưalları değil, her kanun kuralı kötüye kullanılmağa elverişli olabilirn ${ }^{82}$ Esasen varkklı kişilerin bu yola başvurarak boşandıkları da herkesçe bilinen bir gerçektir.

Nihayet Öntasarıda, tazminat talebinin, boşanma kararnndan bașlayarak bir yul içerșinde yapılabilmesine imkân verilmek suretiyle, boşanmadan sonra tazminat talebine hakkı bulunduğunu anlayan eșin ,bu hakkının muhtel olması önlenmiș bulunmaktadır.

\section{B. Yoksulluk Nafakast}

Boşanma kararmın kesinleşmesi ile karı koca arasındaki nafaka mükellefiyeti sona erer. Ancak kanun koyucu kusursuz eşin korunması için md. 144 ile şu hükmü koymuştur : "Kabahatsız olan karı yahut koca boşanma neticesi olarak büyük bir yoksulluğa düşerse, diğeri boșanmaya sebebiyet vermemiş olsa dahi kudreti ile mütenasip bir surette bir sene muiddetle nafaka itasına mah. kûm edilebilir.»

Doktrinde "yoksulluk nafakası» adı verilen bu müessese bir tazminat veya ceza niteliğinde değildir. Çünkü kusursuz eş dahi bunu ödemege mahkûm edilebilir. Amacı, ahlâkî düșünce ve sosyal adalet ilkesi gereği eşin yoksulluğa düșmesini önlemektir. ${ }^{83}$ Anayasamı md. 2 de «oSsyal Hukuk Devleti» ilkesini açıç̧a kabul ederek, ailenin ve kadının korunmasına ilişkin hükümler koymuş. tur. Ancak 5. maddesinde sosyal hakların devletin malî güicü oranunda gerçekleştirilebilineceğini de hükme bağlamıştır. Ülkemizde Devletín yeterli malî güce sahip olmamasi nedeniyle sosyal sigortaların tüm vatandaşları kapsamadığı, sosyal yardım kurum. larınin yeterince gelişemediği gözönünde tutulacak olursa, ancak bir yıl süreyle yoksulluk nafakası alacak olan eş, bu bir yılın bitiminde çalışacak guice sahip değilse, işe girecek yaşı geçmiş ya da uzun süre ara verdiği için mesleğini icra edemiyecek duruma düşmüşse ne yapacaktır? Ona Devletin hangi yardım eli uzanacak. tur?.

Bu anlamasız sinırlamaya karşı Yargıtay dolambaçlı yoldan hareket edip, md. 145/3 ile md. 150/5 i uzlaştırmak suretiyle, yok. sul eş lehine nafakanın süresini uzatmak yoluna gitmiştir. Ihtiyaç.

8kz. Velidedeoğlu, a.g.e., sh. 261; Feyzioğlu, a.g.e., sh. 308; Tandoğan, a.g.e., sh. 103. 
larm zorlamasına karşı, uygulamanın bir tavir takınmasına ve titizliğine ilginç bir örnek teşkil ettiŏ̀ için, Yargıtayın kararın burada zikretmekte fayda görüyoruz.: «Davacı, karısı aleyhine açtı̆̆ı boşanma davasının görülmesi sırasında 5.3.1968 tarihli oturumda karısının boşanmağa muvafakat ettiği takdirde kendisine evlenin. ceye kadar, evlenmediği takdirde ölünceye kadar ayda 300 lira yok. sulluk nafakası vermeyi kabul etmiş ve bu anlaşma Medenî Ka. nunun $150 \mathrm{nci}$ maddesinin son fıkrası hükmü gereğince hâkimlik. çe onanmıştır.

Boșanma kararndan bir yl sonra davacı durumunda değişiklik olduğundan bahsile bu nafakanın kaldırılmasımı istemiştir.

Medenî Kanunun 145 inci maddesinin 3 üncü fikrasındaki hük. mü taraflarca kararlaştırılıp aynı kanunun 150 inci maddesinin 5 inci bendi gereğince hâkimin tasdikine iktiran eden yoksulluk na. fakalarına tatbik olunur. Ancak her hak gibi yoksulluk nafakasının indirilmesi veya kaldırılmasını isteme hakkı da Medenî Kanunun 2 inci madesindeki smırlar içinde kullanılabilir. Akit tarihindeki gelir durumu ve davacının rizasıyla ödemeyi yüklendiği miktar ile aradan geçen zamanın azhığı ve davacının boşanıp evlendiği ikinci karısına hemen gayrımenklûünü devretmesine nazaran davacinın bu isteği hakkın kötüye kullanılması mahiyetini taşıyıp taşımadığı incelenmeden, bu husustaki tarafların delilleri toplanmadan hükmün tesisi yolsuz ve temyiz itirazları bu itibarla varit bulunmadığından hükmün bozulmasına... Oybirliği ile karar verił. dis. ${ }^{84}$

Öntasarı da gerekçesinde "Eğer yoksuluk nafakasının amacı, evvelce ortak bir hayat sürmüs olan eşlerin boşanmadan sonra birbirine yardımı ise, bunun süresiz olması gerekir ve ancak bu durumda yoksulluk nafakasından beklenen sonuç elde edilir» diyerek, ${ }^{85}$ md. 144 ü şöyle düzenlemiştir.

«Mad. 144 - «Boşanmada kusuru olmayán veya kusuru ötekine kiyasla daha az olan eș, boşanma yüzünden büyük bir yoksulluğa düşmüşse öteki eș, boşanmada kusuru olmasa bile, onun geçimi için malî gücü oranında süresiz olarak nafaka ödemeye mahkûm edilir.»

${ }^{34}$ Yt. 2. HD; 20.4.1970, 1864/2567, Ank. Bar. Der. 1971, S. 1, sh. 103.

85 Öntasarn, sh. 138. 
Yeni hükmün ilginç yanı «mahkûm edilir» gibi kesin bir ifade kullanmak suretiyle, şartlar yoksulluk nafakası bağlanmasını gerektiriyorsa, hâkimi bu yolda hüküm vermeğe zorlamasıdır.

Bizce Tasarmın öngördïğui bu değișiklik te yeterli değildir. Gerek Medenî Kanun gerek Öntasarı md. 145 ile nafaka borçlu. sunu koruma yoluna gitmiştir. M.K. md. 145 e göre «Yoksulluğu sebebiyle kendisine nafaka tayin edilmiş olan karn veya kocanın yoksulluğu zail olmuș veya hissolunacak derecede azalmış ise, borçlunun talebi üzerine nafaka kat veya tenzil olunur. Borçlunun malî kudreti nafaka miktarına nazaran azaldığı surette dahi ay. nı hüküm caridir.» Öntasarı md. 145/5 e göre "Yoksulluk yüzünden bağlanan irat, yoksulluk durumu ortadan kalktığı veya önemli ölçüde azaldığı veya borçlunun malî gücüi iradı ödeyemeyecek derecede eksildiği takdirde, borçlunun istemi üzerine indirilir veya büsbütün kesilir.»

Ulkemizde para değerinin büyük bir hıla düştügü, hayat pa. Łalılığının giderek arttığı herkesçe bilinen bir gerçektir. Șu halde rafaka alacaklısının eline geçecek miktarın asgarî ihtiyaçların karşılayabilmesini mümkün kılmak için, ona da gerektiğinde ve di. ğer eşin durumunun müsait olması halinde nafakanın yükseltilmesini talep hakkı tanınmalidır.

\section{\$ 5 - Miras Hükümleri Aracılı̆gyla Karının Korunmast :}

Kişinin yaşadığı sürece sahip olduğu malları ve çeşitli hakları, o ölünce ne olacaktır? Bu soruya verilen cevaplar zamana, toplumların dinsel ve ahlâkî inançlarına, sosyal, siyasal ve ekonomik düş. ünce ve yapılarına uygun düşen mülkiyet anlayışına göre değişmektedir. Aile müessesesi ile yakın ilişkisi bulunan miras hukuku, tarih açısından ele alınacak olursa, mallar üzerindeki hakların topluluk veya topluma ait olmaktan çıkıp aile reisine, daha doğrusu tek bir şahsa bağlanmasından, "şahsî mülkiyet» kavramının doğmasından başlayarak ortaya çıkmıştır. ${ }^{87}$ Kollektivistler özel mülkiyete karşı ol. duklarından, miras hukukunu reddederler. Ancak sosyalist rejimi

86 Ontasar1, sh. 139.

${ }^{87}$ Bu konuda bkz. Topçuoğlu, a.g.e., Durkheim, sh. 52 v.d.; Inan, Miras Hu. kuku. Ank. 1969, sh. 4; P. Koschaker, Modern Hususî Hukuka Giriş Olarak Roma Hususî Hukukunun Anahatları (Kitabı yeniden elden geçiren K. Ayiter), Ankara 1971, sh. 345 v.d.; N. Kocayusufpaşaoğlu, Miras Huku. kuna Giriş, Istanbul 1966, sh. 15. 
gerçekleștirmiş olan ülkelerde, meselâ S.S.C.B.nde bile, ihtiyaçların zorlaması ile dönüşler yapılmış, sınırlı da olsa miras hukukuna yer verilmiştir. ${ }^{88}$ Günümüzde toplumların çok büyük bir kısmı hem aileyi korumak hem de ferdiyetçi görüşten hareketle, miras bira. kanın hakkına hürmet etmek üzere miras müessesesini kabul etmiş ve mülkiyet hakkındaki sınırlamalarla birlikte mütalâa ede. rek, onu toplum menfaatleri ile çatışmayacak biçimde düzenlemişlerdir.

Miras hukuku esas itibariyle kan bağına dayanır. Bu nedenle aslî mirasçılar kan hısımlandır. Hayatta kalan eşin aslî̀, yani kanunî miraş̧ıların yanında yer alıp alamıyacă̆ı ı çșitli zamanlarda ve toplumlarda farkh biçimde düzenlenmiștir. Bașlarda genellikle karımin aleyhine olan durum giderek düzeltilmiş; karı kanunî mirasçılar arasında yer almıs, ayrıca mal rejimleri ve sigortalar aractlı̆̆yla iktisaden korunması esası da gerçekleşme yoluna girmiş. tir.

Modern mevzuatta hâkim olan görüș, miras hukuku yönünden karıya daha çok imtiyaz tanınması yönündedir. Evlenme ile ayrı cinsden iki insan sağlıkta ve hastallkta, varlık ve yoklukta, mutluluk ve acıda kader birliği yaptıklarından, kendilerine en yakın kiși esleri olmaktadır. Şu halde birinin ölümü halinde să kalan eşe, ölen esin sağlığındaki yaşama düzeyini, ekonomik imkânları tanımak âdalete en uygun yoldur. ${ }^{89}$ Kaldı ki çağımızda evlilik birliğinin ekonomik düzeyinde, yani malvarhı̆ında kadının katkısı giderek artmaktadır. Modern mevzuat bu gerçeği idrakle, yeni bir tutum icersine girmiș, geride kalan eșin malî durumunu mal rejimleri ile birlikte mütalâa etmiștir. Bir ülkede eșin miras hakkı onun aleyhine çözümlenmiș ise, kanun koyucu eșin durumunu mal reji. mi aracliğı̆yla düzeltme yoluna gitmiștir. Meselâ Portekiz'de kanunî mal rejimi «mal ortaklığı» olduğundan, geride kalan eș aile mallarının hiç değilse yarısını mal rejimi gereğince almaktadır. Yoksa sağ kalan eş ancak altsoyun ve üst soyun, hattâ kardeșlerin ve kardeș altsoylarmın bulunmaması halinde mirasa müstahak olabilecekti. Böyle bir miras hükmünün . salt uygulanması halinde. să̆ kalan eșin sefalete mahkûm olacağı açıktır.9

\footnotetext{
${ }^{88}$ Fazla bilgi için bkz. 1. Oztrak, Miras Hukuku, Ankara 1968, sh. 3-7; Koca. yusufpaşaoğlut, a.g.e., sh. 22-24.

*9 Aynt görüș için bkz. Inan, a.g.e., s. 61; Kocayusufpaşaoğlu, a.g.e., sh. 77.

${ }^{9}$ Aksoy, a.g.e., sh. 39-40.
} 
Ingiltere'deki hukukî gelişmeler mal ayrilığının kadın aleyhine olan sonuçlarnm gidermek için, sağ kalan eşin miras hakkmı, ölenin kan hısımlarının aleyhine genişletme yönündedir."1 1925 ta. rihli "Administration of Estates Act» ve 1952 tarihli «Intestates' Es. tates Act» ile geride kalan eș, ölen eşin tüm menkûl zatî eşyasını (pesonal chattels), ayrıca altsoy ile karşılaşırsa terekeye dahil mallardan $£ 5000 \mathrm{lik}$, diǧer mirasçlarla birleşirse $£ 20000$ lik kısmını (ölïm anından bu meblağın eșe teslimi anına kadarki $\% 4$ faizi ile birlikte) ö n p a y olarak almaktadrr. Sağ kalan eşin ölenin alt ve üst soyu ile birleşmesi halinde, terekenin bu meblağlardan geri kalan kısmı üzerinde, ilk halde yarısının intifa hakkına, ikinci halde de yarısının mülkiyetine sahip olduğunu görmekteyiz."2

1952 tarihli Kanunun diğer ilginç bir hükmü de, sał kalan eșe belirli şartlar altında, diğer eşin ölümü anında oturulmakta olan evin kendisine devredilmesini talep hususunda seçimlik bir hak tanımıs olmasıdır. ${ }^{93}$ Böylece Ingiltere'deki yeni mevzuat, evliližin ölümle sona ermesi halinde, mal ayrihğından dogabilecek haksızhkklan büyük ölçüde gidermiştir.4

Isveç'te de Ingiltere'dekine paralel bir durum göze çarpmaktadır. Daha önce belirttiğimiz gibi, eşlerden birinin ölümü halinde, belirli mallar dışında eșlere ait olan mallar bir ortaklık teșkil etmekte, geride kalan eș bu malların yarısına sahip ourken, diğer yarısı üzerinde de miras hükümleri gereğince pay almaktadır..$^{95} \mathrm{Mi}$. ras Kanununa göre, evli bir şahıs ölünce, ikinci parantelden akra. bası yoksa, geride kalan eş bütün terekeyi tam mirasçı olarak alır. Ancak ölenin ikinci parantelden mirasçları varsa, să̆ kalan eş terekeye sahip olmakla beraber, tereke uizerindeki haklan belirli ölçüde sınırlanır. Yani $o$, terekenin miras hükümleri gereğince kendisine düșen yarısı üzerinde vasiyetle tasarrufta bulunamaz. Çünkü o da ölünce, her iki eşin mirasçlları evlilik mallarını paylasacaklardir.

Aile hukuku içerisinde yer alan, fakat mahiyeti itibariyle miras hukukuna iliş̧kin diğer bir hükme göre, malların paylaştırılma. sında kendisine düşen mallar çok az ise, sağ kalan eş, eşlerin or-

\footnotetext{
${ }^{9}$ Friedmann, a.g.e., sh. 244; S. \$. Ansay, Aile ve Miras Hukuku Sahasinda. ki Ingiliz Harp Sonrası Teşrii, AHFD, 1955, C. XII, S. 1-2, sh. 360 ,

92 Hanish, a.g.e., sh. 85-87.

93 Hanish, a.g.e., sh. 87.

94 Hanish, a.g.e., sh. 95.

\$s Bz. yukarida \$ 3-B.
} 
taklhk mallarnndan gerek!i ev eşyasını, çalışma için gerekli aletleri ve çalışma faaliyetlerini sürdürebilmesi için ihtiyacı olan diğer menkulleri alma hakkına sahiptir.\%

Almanya'da ise, kanun koyucu miras hükümleri ile mal rejim. Irrini kaynaștırma yoluna gitmiştir. Sağ kalan eşin miras hakkı tcsbit edilirken, eşler arasında kabul edilen mal rejimine bakıllır ve buna zöre miras payı her defasında farklı olur. Kanunî mal rejiminde ise esâs şudur: "Mal rejimi eşlerden birisinin ölümüi ile sona ererse, artan kazancın denkleștirilmesi, geride kalan eșin kanun! miras payının terekenin $1 / 4$ ù oranında çoğaltılmasıyla gerçek. ieșiirilerektir (verwirklicht); bu hususta, münferit hallerde eşlerin bir kâzanç fazlalığı sa:̣̆layıp sağlamamıș olmaları önemli değildir» (BGB § 1371/I).97

Kanun koyucu evliliklerin $\% 80$ inin ölümle sona erdiğini göz c̈nünde tutarak, geride kalan eşin, evlilikteki ortak çalıșmaların ürünlerinden payını almasını böyle sade ve açık bir hükümle çözïmleme yoluna gitmiștir..$^{98}$ Böylece ölüm halinde artmıs kazancm paylaștırılması yerine, geride kalan eşin miras hakkı çoğaltılmıştrr. Burada mallarda artma olup olmadığı veya eşlerden hangisinin kazancının fazla bulunduğu soruları da söz konusu olmayacaktır.99 Geride kalan eş ayrıca, altsoyun (çocuklarnn) yanında terekenin $1 / 2$ si (BGB § 1924), ana baba ve altsoylarının yahut büyük-ana ve baba yanında terekenin 3/4 ü (BGB 1925, § 1926) üzerinde kanunî mirasçl olarak hak sahibidir. ${ }^{100}$

Öte yandan Kanun $\S 1371 /$ II ile geride kalan eşe, dilerse "çogaltılmı miras payı yerine «artmıs kazancın paylaștırılması"nı talep etme hakkını tanımıștır. Șöyle ki : Sağ kalan eșin kusuru nedeniyle aleyhine boşanma veya iptal davası açılmış, ölen eș ölüme bağ̆lı bir tasarrufla să̆ kalan eși mirastan iskat etmiş, sağ kalan es mirastan mahrumiyeti gerektirecek bir duruma girmiș, mirastan feraggat eımiș ya da mirası red etmiş ise, ${ }^{101}$ mirasçlılk sıfatı ortadan falkacağından, bu durumda uğrayacağı zararı gidermek için bu se. çimlik hakka sahip kılınmıştır.

\footnotetext{
F́ Ayruntılı bilgi için bkz. a.g.e., sh. 114 v.d.

${ }^{97}$ Scheffler-Koeniger, a.g.e., sh. 146, § 1371/1; Dölle, a.g.e., sh. 779.

98 Scheffler-Koeniger, a.g.e., sh. 147, Anm. 1.

103 Scheffler-Koeniger, a.g.e., sh. 149, Anm. 9; Dölle, a.g.e., sh. 779-80.

101 Scheffler-Koeniger, a.g.e., sh. 153, Anm. 24 v.d.; Dölle, a.g.e., sh. 790.93.
} 
Bundan başka "Gleichberechtigunggesetz", geride kalan eșe ev idaresine dahil eşyayı (Haushaltsgegenstande veya Hausgut), ${ }^{120}$ ikinci paranteldeki miraş̧ların yanında, ȩ̌er bu eşyaya muhtaç ise, *önpay* olarak alma hakkını tanımıştır (BGB $\S 1932) .^{103}$

Ûlkemizdeki duruma gelince. Bilindiği üzere biz de Isviçre Medenî Kanunu gibi Pandekt Hukukundan gelen ve önceleri Isviç. re kantonlarının çoğunda hâkim bulunan «mirasçılık kan hısımlarının imtiyazıdır” fikrini terkederek, eșe kanunî mirasçılık sıfa. tını tanımıs bulunuyoruz (M.K. md. 444). Eger :

a) Miras bırakanın I, II ve III. parantelden hiçbir mirasçısı yoksa, sağ kalan eş tek başına mirasçıdır ve miras payı terekenin tamamını kapsar (md. 444/2).

b) I. parantel, yani fürû bir birlikte mirasçı olan eş seçimlik hakka sahiptir. Ya terekeyi teşkil eden mal ve hakların 1/4 ünün mülkiyetini ya da $1 / 2$ sinin intifa hakkını alır (md. 444/1).

c) Eş II. parantel ile birlikte mirasçı olursa, terekenin 1/4 ïnün mülkiyetini, 1/2 sinin de intifamı alır (md. 444/2).

d) Eș III. parantel ile birleşirse terekenin $1 / 2$ sinin mïlkiye. tini ve $1 / 4$ ünün de intifainı alır (md. 444/2).

Aile üyeleri arasındaki kuvvetli duygusal bağlar onları, imkân nisbetinde, yakınlarının geleceklerini düşünmeğe ve tedbirler alma. ğa zorlar. Bu gerçek kanun koyucuları, bazı kanunî mirasçllara miras burakanın iradesi ile ortadan kaldırılamayan bir bir miras hissesi tanımağa yöneltmiştir. "Mahfuz hisse» adı verilen bu dokunulmaz miras payı, başlangıçta kan hısımlarına münhasır iken, za. manla eșleri de kapsamına almıştır. Ülkemizde de, kanun koyucu, özellikle mal ayrıhı̆ının zararlarını gidermek amactyla geride kalan eşe bir mahfuz hisse tanımıștır. ${ }^{\text {in }}$ Ancak bu çözüm tarzı, artık günümüzün ihtiyaçlarını yeterince karşılayamamaktadır. Evlilik birliğinde önemli olan, her bakımdan kader birliği yapmış eşlerin, birisinin ölümü halinde, sağ kalanın ölümünden önceki durumunda kötüleşme olmamasıdır. ${ }^{105}$ Dikkat edilecek olursa, miras hukuku yö.

$102 \mathrm{Ev}$ eşyaşı evde barnnmayı ,giyinmeyi yemek yemeği, evin döșenmesini, ev işlerinin görülmesini mümkün kılan tüm eşyalarıdır. Ayrıntıı̀ bilgi içia bkz. Dölle, a.g.e., sh. 767; Scheffler-Koeniger, a.g.e., sh. 135-37, Anm. 6 v.d. 103 Aksoy, a.g.e., sh. 181-82; Dölle, a.g.e., sh. 767.

${ }^{104}$ Bkz. Kocayusufpaşaoğlu, a.g.e., sh. 77 d.n. 1.

10s Ayn görüss için bkz. H. C. Oğuzoğlu, Medenî Hukuk, C. II, 4. Bası, Ankara 1958, sh. 191. 
nünden sağ kalan eş giderek ön plâna geçmektedir. Pek çok ülkede uzak kan hısımları miras dıșı bırakılmakta, ya da mahfuz hisseli mirasçılara karşı (müşterek çocuklar dışında kalan) geride kalan eşin miras hissesinin vasiyet yolu ile çoğaltılmasına imkân verilmektedir. Ülkemizdeki kanunî mal rejimi nedeniyle, özellikle karı. nın durumu kocasının ölümü üzerine kötüleșmektedir. Kadın dıșarnda veya evde çalışarak, kocasına maddî yönden destek olduğu halde, evlilik süresinde ortaya çıkan fazlalık ve kazançtan yeterli bir pay alamamaktadır. Çoğu kez çalışan kadının kazancı ile alınmıs veya sağlanmıș herșey, bizdeki ataerkil aile düzeninin de etkisiyle, kocanın mülkiyetine dahil olmakta, dolayısıyla kocanın terekesine girmektedir. Böylece kadın kendi malını, bazen hiç ilgisiz koca hrsımları ile paylaşmak durumunda kalmaktadır. Koca karısını bağıs veya vasiyet yolu ile korumağa kalksa, bu kez mahfuz hisseli mirasçılar tenkis davaları ile karşımıza çıkmaktadırlar. Esasen bizde anlaşılan şekliyle, katı bir mahfuz hisse telâkkkisi, günümüzün sosyal âdalet ve hukuk anlayışına da aykındır. ${ }^{106}$

tsviçre M.K. sağ kalan eşin miras hissesini bizdekinden daha iyi çözümlemiştir. Şöyle ki, să̆ kalan eş II. ve III. paranteldeki mirasçılarla (yani ölenin anası babası veya bunların füruu) birleș. tiğinde, terekenin $1 / 4$ ünün mülkiyeti ile $3 / 4$ ünün intifamı almak. ta ;III. paranteldekilerle (ölenin büyükanası ve babası veya bunla. rin füruu) birleştiginde, terekenin $1 / 2 \operatorname{sinin}$ mülkiyet hakkını ve diğer yarısının da intifaına sahip olmaktadır (ZGB md. 462) ${ }^{107}$ Böylece sağ kalan eş, terekenin tümüne zilyed olmakta ve ölünceye kadar bu terekenin tamamindan yararlanmaktadır. ${ }^{109}$ Sağ kalan eșin altsoyla karşılaşması halinde, çözüm tarzı bizdeki gibidir. Ancak ZGB md. 473 e göre muris, altsoyla karşılaşan eşe, ölüme bağlı bir tasarrufla, terekenin tamamının intifa hakını bırakabilmektedir. Biz de ise böyle bir imkân mevcut değildir.

Eşin intifa hakkına gelince, ülkemizde geregince uygulama ala. nı bulamamıs, kendinden beklenen yararı sał̆layamadı̌̆ı gibi, mi-

\footnotetext{
${ }^{106}$ Aksoy da mahfuz hisse sistemizin günün huksk anlayıșına, küçük aile kavramına, sosyal devlet anlayıșına aykın düștüğii kanısındadır. ag.e., sh. 204, 205 d.n. 503.

${ }^{107}$ Bkz. s. Gönensay-K. Birsen, Miras Hukuku, 2. Bası, Istanbul 1963, sh. 28, d.n. 2.

${ }^{108}$ Bkz. K. Oguzman, Miras Hukuku Dersleri, tstanbul 1972, sh. 73; Aksoy, a.g.e., sh. $89-90$.

${ }^{109} \mathrm{Bkz}$. Aksoy, a.g.e., sh. $90-91$.
} 
rasçılar arasında anlaşmazlıklara, ve şikayetlere, içtihatlarda devamI tereddütlere yol açmıştır. ${ }^{10}$ Veraset ilâmlarının her hangi bir varis tarafından çıkartılabilmesi, özellikle Anadolu'da mahkemeye gelmeyen eșin aleyhine olmaktadır. Veraset ilâmma eșin intifa hakkını seçmiş olduğu kaydettirìlerek sahtekârlıklar yapılmaktadır. Bundan sonra, uygulamada çok görüildüĭgi ïzere, mirasçlar hemen terekenin toptan satışı yoluna giderek, intifa hakkı sahibi eşi güiç duruma sokmaktadırlar. Meselâ terekenin satıșindan 50000 lira elde edilse, bunun 1/4 ü olan 12500 lira bankaya konmakta, să kalan eş te bu meblağın sadece faizi ile yetinmek zorunda kalmakta. dır. ${ }^{\text {II }}$ Her nekadar intifa hakkını gereğince kullanan kişilere rastlanmaktaysa da, bunların sayısı parmakla gösterilecek kadar azdir. ${ }^{122}$

Tanınımıs hukukçuların çoğunluğu ve modern kanun koyucular miras hukuku ile mal rejimleri arasındaki yakın iłişkiyi açıça görüp belirtmektedirler: E. Huber'in açıkça ifade ettiği gibi, mi. ras hukuku geride kalan eșin miras hakkı bakımından karı koca mal rejiminin tamamlayıcısı olma görevini yüklenmelidir. ${ }^{13} \mathrm{Bu}$ nedenle, ülkemizde mal aynlığı kanunî rejim olarak muhafaza edilecekse, geride kalan eşin miras payının, diğer eş hayatta iken sürdüğü hayat tarzını karşılayacak oranda yükseltilmesi gerekir. Bu arada, uygulamada devamlı güçlükler çıkaran ve anlaşmazlıklar doguran intifa hakkını da mülkiyet esasına çevirmek yararlı olur."14

Medenî Kanun Öntasansına bakacak olursak, Medenî Kanunun md. 444 e tekabül eden md. 446 da sağ kalan eşin miras payı şöyle düzenlenmiştir :

"Sağ kalañ eş miras bırakanın :

1) Altsoyu ile birlikte mirasçı olursa, mirasın 1/4 ini;

2) Baba ve ana takımı ile birlikte mirasçı olursa, mirasın yarisini;

3) Dede ve nineler takımı ile mirasçı olursa, mirașın 3/4 ünü,

110 Ontasar1, sh. 402.

II H. H. Sungur, Kanunî Mirasçllarin Memleket thtiyaçlarına Uygun bir Şe. kilde Değiștirilmesi Lüzumu, (5. Rapor) Muk. Hukuk Araş. Der. 1958, S. 2, No. 2, sh. 88 v.d.

112 Bkz. 5. Rapor Tartışaları:

${ }^{13}$ Aksoy, a.g.e., sh. 44.

114 Öntasarı, sh. 403. 
4) Dede ve nineler takımından mirasçı yoksa, mirasın tamamını miras payı olarak alırs. ${ }^{135}$

Görülüyor ki, Öntasarı intifa hakkını, yukarıdaki gerekçelere dayanarak kaldırmıș, daha doğrusu mülkiyete çevirmiştir. Fakat sağ kalan eşin miras payını tesbit ederken, eski zihniyeti sürdürmüş. tür. Özellikle 1. ve 2. fıkralardaki çözüm tarzı günümüzün ihtiyaç. larına ve sosyal âdalet anlayışına aykırıdır. Bu düzenlemede karnın ailenin malvarlığına katkısı gene göz önüne alınmamış; çoğu kez karının kazancının ürünü olan malvarlığı adetâ kendisinden koparılıp alınarak, belki de hiç ihtiyacı olmayacak kimselere verilmiştir. ${ }^{116} \mathrm{Bu}$ nedenle, yeni çözüm tarzı, M.K. dakinden biraz daha iyi ise de, ülkemizde etkisini açıkça gösteren sosyal ve iktisadî alandaki değişiklikler, sosyal adalet ve kadın haklarına ilişkin gelişmeler karșısında gene de bir gerilik ve haksızlık teşkil etmektedir.

\section{SONUÇ}

Yaptığımız araştırma göstermiştir ki, 19. yüzyılın sonlarundan başlayarak huzlanan ekonomik ve sosyal değişmeler, gelişen demokratik zihniyet, iktisaden zayıf olanı korumağa yönelik «sosyal hukuk devleti»nin gerçekleşmesine yol açmıștır. Sosyal hukuk devleti de aile müessesesinin eski ataerkil düzenine karşı çımış, aile hukuku ve mal rejimi alanlarında, karı lehine yeni düzenlemelere git. miştir. Böylece, bir yandan kocanın aile malları üzerindeki idarî yetkileri kısttlanırken, bir yandan da karını bu malların idaresine katılması sağlanmıștrr. Geliş̧me bu kadarla da kalmayarak, kadının aile içindeki veya dışındaki çalışması değerlendirilmiş, ev. lilik süresinde kazanılan mallar üzerindeki hakkı teslim edilmiştir.

Surası bir gerçektir ki, mal ayrılı̆̆g kadına bağımsızlığını ka. zandırmada önemli bir görev ifa etmissse de, artık karının yeni du. rumu nedeniyle, itibarm yitirmiștir. Nitekim bu rejimde ssrar eden ülkeler bile, onun karı aleyhine yarattığı haksızlıkları giderecek hukukî tedbirler almışlar ve almaktadırlar. Modern kanun koyucular, artık karı kocanın aile birliği içersindeki fonksiyonlarını birlikte mütalâa etmektedirler. Gerçekten de karı koca, birliğin mutluluğu ve refahı için, görev paylașması yapmışlardır. Bu görev ayrımında karının faaliyeti, kocanınki gibi, her zaman gözle görülen bir

115 Öntasarı, sh. 416.

$116 \mathrm{Bu}$ konudaki haksizlık örnekleri için bkz. Aksoy, a.g.e., sh. 202-204. 
kazanç şeklinde olmayabilir. Şu halde, bu ortaklaşa çabanın semerelerinden eşlerin birlikte yararlanmalarnm gerçekleștirmek gerekmektedir. Nitekim, pek çok ülkede eşler arasındaki manevî dayanışmanın iktisadî yönden de sağlandığına, kadın emeğinin değerlendirildiğine, kocanın kazancına haklı olarak iştirak ettirildiğine şahit olmaktayız.

Ülkemizde de bu soruna eğilme zamanı gelmiștir. Bugün, «mal ayrlhğı bünyemize ve geleneklerimize en uygun rejimdir» iddialarn dayanaksız bir uhaklı çıkarma ameliyesiınden başka bir şey değildir. 1926 yılında başladığımız büyük hukuk reformunu sürdürmek zorundayız. Her ne kadar örf âdetin hukúku etkilediği; biçimlendirdiği doğru ise de ,bunun aksi de bir gerçektir. Iyi bir kanun koyucu bilinçli çabalarla birer baskı aracı haline gelen, ihtiyaçları karşllayamayan, eskimiş ve köhnemiş örf-âddeti değiștirebilir ve değiștirmelidir. Bu nedenle kanun koyucumuzun, özellikle aile birliğinin sona ermesi halinde, kadının içine düstüŭgu kötü durumu dikkate alarak yeni bir kanunî mal rejimi araması, onu iktisaden koruyacak nafaka ve miras hükümlerinde değişiklik yapması gerekmektedir. 
B I B L I Y O G R F Y A

Akıntïrk, T.

Aksoy, $\mathrm{M}$.

Ancel, $\mathbf{M}$.

Arsal, S. $\mathbf{M}$.

Bilge, N.

Boschan, S.

Boehmer, G.

Carbonnier, J.

Desbois, M. H.

Dölle, $\mathbf{H}$.

Egger, A.

Elbir, H. K.

Esener, T.

Feyzioğlu, N. F. Friedmann, W.
: Aile Hukuku Dersleri, Ank. 1967

: Mukayeseli Hukuk Açısından Karı Koca Mal Rejimi ve Miras Hukuku tle Bağ, Ank. 1964

: «Matrimonial Property Law in France," in Matri. monial Property Law (Ed. by W. Friedmann), London 1955

Aile ve Miras Hukuku Sahasındaki Ingiliz Harp Sonrası Teşri'i, AHFD, 1955, C. XII, S. 1-2

: Türk Tarihi ve Hukuk, I. C., Ist. 1947

: Eşler Arasında veya Karı Koca Menfaatına Ka. n ile üçüncü Kişiler Arasında Yaplan Hukukî Muamelelerin Yargıç Tarafından Tasvibi, AHFD, 1951, C. VIII, S. 1-2

: Europä isches Familienrecht, 5. Auflage, München 1972

: Europäisches Familienrecht, 5. Auflage, Münc. gen 1954

: Droit Civile, Tome 2, Paris 1969

: «France», Le Régime Matrimonial Légal dans les Législations Contemporaines (Direc. A. Rouast; J. B. Herzog; I. Zajtay), Paris 1957

: Familienrecht, Band I, Karlsruhe 1964

: Sosyal Medenî Hukuku veya Bugünkü Medenî Hukukta Cemiyet ve Fert (Çev. H. Veldet), Ank. 1938

: Boşanma Halinde Maddî ve Manevî Tazminat ve Nafaka Haklarinın Toplu bir Tetkiki, Ist. Bar. Der. 1948, S. 1

: Boşanmadan Mütevellit Maddî ve Manevî Zararın Tazmini Ne Zamana Kadar Talep Edile bilir? AHFD 1951, C. VIII, S. 1-2

: Aile Hukuku Dersleri, 1st. 1971

: Law in a Changing Society, Berkeley and Los Angeles 1959

Friedmann, W. (Ed.) : Matrimonial Property Law, London 1955 
Gönensay, S. .

Birsen, $\mathbf{K}$.

Hanish, $\mathbf{H}$.

Hodges, H. M.

Inan, A. N.

Kahn-Freund, O. : «Matrimonial Property Law in Sweden», in Mat. rimonial Property Law

Kocayusufpaşaoğlu, N. : Miras Hukukuna Giriş, İst. 1966

Koschaker, $\mathbf{P}$.

Kuntkan, A.

Malmström, A.

Masfeller, F.

Mayntz, $R$.

Oguzman, M. K.

ogruzoglu, H. C.

Öztrak, 1.

Pound, $\mathbf{R}$.

Pound, R.

Rouast, A.

Saymen, F. H. Elbir, H. K.

Scheffler, G. -

Koeniger, $\mathrm{H}$.

Schwarz, A. B.

Sungur, H. H.

Tandoğan, $\mathrm{H}$.

Tekinay, S. S.

Tepeci, $K$.

Topçuoğlu, H.

: Miras Hukuku, İst. 1963

: Die Moderne Tendezen der Englischen Ehegü terrechts, Berlin 1963

: An Introduction to Sociology, New York 1971

: Erkek Kadın Hukukî Müsavatı Alman Aile Hukukunda Ne Gibi Degisisiklikler Yapacak ve bu Değişiklikleri Içine Alan 2. Kanun Tasarısının Hïkümleri, AD 1956, S. 8

: Modern Hususî Hukuka Giriş Olarak Roma Hu. susî Hukukunun Anahatları (Kitabı yeniden el. den geçiren K. Ayiter), Ank. 1971

: Köy Sosyolojisi, tst. 1968

: Matrimonial Property Law in Germanys, in

: «atrimonial Property Law in England, in Mat. rimonial Property Law

: Die Moderne Familie, Stuttgart 1955

: Miras Hukuku Dersleri, Ist. 1972

: Medenî Kanunumuzun Mahfuz Hisse Ielâkkisi, AHFD 1951, C. VIII, S. 3-4

: Miras Hukuku, Ank. 1968

: The End of Law as Developed in Legal Rules and Doctrines, 27 Harv L. Rev.

: A Survey of Social Interests, 57 Harv. L. Rev.

: Le Régime Matrimonial Légal Dans Les Législa. tions Contemporaines, Paris 1952, Introduction Comparative

Türk Medenî Hukuku, c. III, Aile Hukuku, tst.

$: 1960$

Das Bürgerliche Gesetzbuch, IV. Band, 1. Teil,

: Berlin 1960

: Aile Hukuku (Çev. B. Davran), 2. Bası, Ist. 1946

: Kanunî Mirasçılann Memleket thtiyaçlarnna Uy. gun Bir Şekilde Değiştirilmesi Lüzumu (5. Ra. por), Muk. Huk. Araș. Der. 1958, S. 2, No. 2

: Aile Hukuku Ders Notlar (Teksir) (Tasnif ve Cüz'i Ilaveler Yapan N. Ayiter), Ank. 1965

: Türk Aile Hukuku, tst. 1971

: Notlu ve Izahlı Türk Kanunu Medenisî, Ank. 1955

: Hukuk Sosyolojisi Ders Notları (Teksir), Ank. 1972.73 
Türk Medenf Kanunu Ön Tasarısı ve Gerekçesi, Ank. 1971

Velidedeoğlu, H. V. : Türk Medenî Hukuku, C. II, Ajle Hukuku; tst. 1965

Velidedeoğlu, H. V. : Türk Medenî Hukuku, Umumî Esaslar, Şahsin Hukuku, Aile Hukuku, Miras Hukuku, Esya Hukuku, Ist. 1963, 3. Basi

Yazıc1, H. Sahıs, Aile ve Miras Hukukunda Yargıtay TatbiAtasoy, $\mathbf{H}$.

: katı, 1952-1970, Ank. 1970 